[Authors' final version]

\title{
STATE CAPITALISM AND PERFORMANCE PERSISTENCE OF BUSINESS GROUP AFFILIATED FIRMS: A COMPARATIVE STUDY OF CHINA AND INDIA
}

\begin{abstract}
Business groups emerged in developing economies through direct or indirect support from the state in order to overcome a variety of institutional voids and/or to further state objectives of economic growth. However, the efficacy of this organizational form and its associated governance structures have been debated given the dual possibility of business groups to allocate resources amongst its affiliates for crosssubsidization or winner-picking. We argue that elements of the institutional environment comprising of the state's approach to organizations and the political context of these interactions vary across countries, thereby influencing business groups' resource allocation strategies and affecting the persistence of affiliated firms' superior performance. Contrasting the types of state capitalism in China and India, we develop and test our hypotheses. We find that the effect of business group affiliation on firms' superior performance persistence is stronger in a state-led system of state capitalism (e.g., China) than in a cogoverned system (e.g., India) and that this divergence of the business group effect is weakened as affiliated firms internationalize. Our findings have implications for understanding business groups across institutional contexts and the influence of diversity in the types of state capitalism on organizational strategies.
\end{abstract}

Keywords: Business groups, comparative institutionalism, state capitalism, performance persistence, China, India 


\section{INTRODUCTION}

Business groups (BGs) are an important part of the organizational landscape in many countries (Carney, Gedajlovic, Heugens, Essen, \& Oosterhout, 2011; Colpan, Hikino, and Lincoln, 2010). An important advantage of BGs is their role as an intermediate organizational form that can function as an internal market for resource allocation; they not only fill "institutional voids" when external markets fail (Khanna \& Palepu, 2010: 6) but can also remain a source of advantage for affiliated firms in competitive market environments (Lamin, 2013; Manikandan \& Ramachandran, 2015). However, individual affiliates do not benefit equally from BG internal markets, as BGs coordinate internal resource allocation strategically, and this may not align with the interests of individual affiliates (Gubbi, Aulakh \& Ray, 2015).

The current literature presents two main internal resource allocation patterns in BGs. When responding to intensifying external market competition, BGs can allocate internal resources in a crosssubsidizing pattern to smooth environmental turbulence and offset survival threats to affiliates (Gopalan, Nanda, \& Seru, 2007; Jia, Shi, \& Wang, 2013; Lincoln, Gerlach, \& Ahmadjian, 1996). Alternatively, BGs can restructure and upgrade the competitiveness of their affiliates (Khanna \& Palepu, 1999) by concentrating resources to strengthen their core businesses (Ghemawat \& Khanna, 1998; Siegel \& Choudhury, 2012), enabled by a "winner-picking" pattern of resource allocation (Cestone \& Fumagalli, 2005: 194). As a result, the performance persistence of a high-performing affiliate of a BG will either be weakened if it is required to subsidize weaker members or be strengthened if it is picked as the winner to receive prioritized support. Given these diverging consequences, it is important to understand the factors influencing BGs' choices between these internal resource allocation strategies.

We investigate this from an institutional perspective and propose that BGs' choice between these alternative resource allocation mechanisms depends on the type of institutional environment from which they originate, which in turn alters the BG affiliation effect on the persistence of superior firm performance. Institutional contingencies are key to understanding how affiliation with BGs influences member firms (Carney et al., 2011). From a theoretical standpoint, BG institutions that govern internal behaviors, such as resource allocation, and external institutions that govern the country economy "play a 
complementary role in the governance of a firm when both exist and interact" (Chittoor, Kale, \& Puranam, 2015: 1278). Our focus on the interaction of BGs and country-level institutions is also motivated by empirical evidence that BGs tend to converge on their resource allocation patterns within a country but differ systematically across countries (Khanna \& Yafeh, 2005). Since "group attributes cannot (easily) explain intercountry differences" (Khanna \& Yafeh, 2005: 333), we aim to offer countrylevel explanations for BGs' resource allocation pattern from an institutional perspective.

Prior studies have examined the functioning of BGs' internal institutions under varying degrees of external institutional development (Chacar \& Vissa, 2005; Chittoor et al., 2015). However, country institutions differ not only in degree of development but also in type (Jackson \& Deeg, 2008). In the emerging economy contexts, especially among Asian economies, the development of market institutions does not replace the critical role of the state in governing the economy (Carney \& Witt, 2014; Hancké, Rhodes, \& Thatcher, 2007). The nature of state-business interaction in economic governance can vary across countries, constituting varieties of state capitalism.

The functioning of BG internal institutions across types of state capitalism remains unexplained in the literature. As an initial attempt to theorize the varieties of state capitalism based on the institutional dimension of state-business interaction in economic governance, this study contrasts the state capitalist systems of the world's two largest emerging economies - China and India. The states of China and India both mix developmental and predatory elements in their overarching economic influence (Carney \& Witt, 2014; Witt \& Redding, 2013), and both are extensively involved in directing their economies, with substantial influence via state-owned firms (Kohli, 2004; Nee \& Opper, 2007). However, "statecraft" in China and India differs substantially (Khanna, 2007: 31), reflected in very different power dynamics between the state and the business sector in economic governance. Using the typology of Zhang and Whitley (2013: 306), China and India generally represent "state-led" and "[state and business] cogoverned" types of state capitalist systems, respectively. ${ }^{1}$ On the basis of this distinction, we elaborate on how BGs differ systematically in their resource allocation behaviors to respond strategically to the statebusiness power dynamics across these two countries. 
Our theory draws on neo-institutional theory and the active agency of firms, which jointly explain firms' various strategic behaviors when interacting with external institutional actors (Oliver, 1991). Specifically, varying power dependency between organizations and institutions can lead to different organizational strategies of legitimizing, ranging from more compliance-based strategies as emphasized by neo-institutional theorists to more self-serving strategies reflecting active agency (Oliver, 1991; Suchman, 1995). We argue that in a state-led system such as China, BGs seek legitimacy by complying with state mandates, whereas in a co-governed system such as India, BGs build legitimacy by negotiating with the state based on their social, economic, and political power. Hence, Chinese BGs tend to engage in winner-picking to align their internal institution with the state's developmental economic policies and priorities, whereas Indian BGs have a greater incentive to build social and political influence and enhance their negotiation power vis-à-vis the state while maximizing self-interest, thus maintaining and expanding their scale and scope through cross-subsidizing. Moreover, we argue that such diverging practices of BGs are less impactful for an affiliated firm when it internationalizes. Resource gains from BG winner-picking are less effective for international competition, while the cross-subsidization effect is also weakened as the affiliate builds partnerships abroad and reduces operational and resource dependency on the business group. In other words, contact with new markets and institutional environments abroad reduces the home country's institutional effects. Empirically, we find support for the proposed performance persistence differentials based on the analyses of a panel of Chinese and Indian publicly listed firms over the period 2005-2010 after controlling for differences arising from BG and firm-level characteristics. ${ }^{2}$

This study makes several contributions. First, it contributes to research on the interaction between BGs and institutional contexts by offering new insights into institutional variations arising from the different state capitalist systems in the two largest emerging economies. Second, existing BG research presents two opposing resource reallocation mechanisms, namely, cross-subsidizing and winner-picking. Integrating arguments related to institutional diversity and organizational response, we reconcile these opposing mechanisms by showing how the institutional environment influences the relative manifestation of each resource allocation strategy. Third, this study extends research on comparative institutionalism, 
which has important implications for international business research into cross-country differences (Jackson \& Deeg, 2008). Prior studies employing the comparative approach have predominantly focused on the diversity of developed institutional systems, such as those of OECD countries (e.g., Hall \& Soskice, 2001; Hotho, 2014); and have recently expanded into other contexts (e.g., Witt et al., 2018). Extending this research stream, this study applies a comparative approach to examine the diversity of emerging economies with relatively underdeveloped formal institutions and state-directed capitalism.

\section{THE ROLE AND POWER OF THE STATE IN ECONOMIC GOVERNANCE}

Political economists have highlighted the varying role of the state in the economic governance of countries. States can vary in their overarching postures toward national economic life, which can be regulatory, welfare-oriented, developmental, or predatory in nature (Carney \& Witt, 2014; Whitley, 2003). The role of the state is also interdependent with other dimensions of country institutions in forming an internally consistent institutional configuration that underlies the different types of capitalist systems or national business systems (Hancké et al., 2007; Whitley, 1999; Witt \& Redding, 2013). Among them, those systems that center on the view of economic statism, in which the state plays a major, necessary, and legitimate role in directing the economy, such as in China (Li, Cui, \& Lu, 2014; Nee \& Opper, 2007) and India (Kohli, 2006a, 2006b, 2007), are often referred to as state capitalism (Carney \& Witt, 2014). In a state capitalist system, the state requires power relative to other economic actors to perform its role of economic governance. The power dynamics between the state and non-state economic actors, primarily in the business sector, are influenced by their mutual dependency and, more specifically, by the possibility and costs of the state (business) to afford an alternative economic (political) agent to achieve its goals.

From the perspective of business organizations, the possibility and costs of an alternative political agent are determined, to a large extent, by the political system in the country. For instance, in a unitary, one-party political system, the state's power is concentrated, and decision-making occurs by fiat. Switching to an alternative political agent is highly costly (e.g., regime change through revolution). Businesses are therefore less able to resist the state's directive economic policies. Kohli (2004) demonstrates how unitary political systems during certain historical periods in South Korea (dictatorship) 
and Brazil (military rule) allowed those countries to implement state-directed economic growth strategies. By contrast, in a federal multiparty political system, given the electoral channel of switching the political agent, the public has more voice and power. Therefore, the "states are not in a position to define their goals ... narrowly" (Kohli, 2004: 11), and the state's decision-making is based on a consensus of multiple constituents, giving business organizations the opportunity both to build appropriate coalitions and to resist institutional demands that may adversely affect their goals.

By contrast, from the perspective of the state, the possibility and costs of an alternative economic agent are influenced by the state's direct involvement in business activities. An important feature of state capitalism is that the state may maintain direct involvement in the economy through state-owned enterprises (SOEs) (Musacchio et al., 2015) as an alternative to private businesses. SOEs give the state the option to influence the economy "either by owning majority or minority positions in companies or through the provision of subsidized credit and/or other privileges to private companies" (Musacchio \& Lazzarini, 2012: 3). Countries may also differ in how the state and private business systems are specialized in the national economy, where they may be either interwoven in all strategic sectors or largely separated into different sectors. If the two types of business are interwoven and thus compete with each other, their coexistence gives the state the choice between the two types of businesses as alternative engines of economic growth (Kohli, 2004). As the state can vacillate between affording primacy to each type of business to achieve its economic goals, it reduces its economic dependency on business organizations while increasing its own power to ensure compliance with its expectations. By contrast, if SOEs and private businesses operate separately in different sectors, their direct competition can be avoided, and private businesses can improve their bargaining power vis-à-vis the state. For example, the economic model of South Korea in the 1960s-1970s relied on the private sector as the engine of growth (Kohli, 2004), leading to the emergence of large private BGs with significant economic, social, and political influence.

Overall, while the state plays the central role of economic governance in state capitalist systems, the power dynamics between the state and business can vary substantially. The power of the state is 
[Authors' final version]

greater when the political system is unitary rather than pluralistic and when the state can alternate between SOEs and private businesses to achieve economic goals. The variation in the power of the state is therefore a key factor in distinguishing the types of state capitalism.

\section{China and India as Distinct Types of State Capitalism}

China and India, the two largest emerging economies in the world, share strong similarities in terms of the degree of their formal institutional development ${ }^{3}$, the prevalence of BGs in the economy (Khanna \& Yafeh, 2007; Carney, Shapiro, Tang, 2009), historical parallels of institutional evolution, and the changing roles of state and private business systems (Khanna, 2007; Witt \& Redding, 2013). However, they also represent two distinct types of state capitalist systems in which the power dynamics and interaction between the state and BGs differ significantly. ${ }^{4}$ Focusing on the varieties of state capitalism in Asia, Zhang and Whitley (2013) propose a typology of political-economic organization based on the state's direction of the economy and business coordination of economic action. China and India both have states that are highly involved in directing the economy (Khanna, 2007; Kohli, 2004; Nee \& Opper, 2007; Witt \& Redding, 2013), albeit in different ways. Moreover, they vary in terms of the power of the state relative to business and hence in the level of business coordination of economic action. Largely consistent with the typology of Zhang and Whitley (2013), China represents a state-led variety of capitalist development, whereas India represents a co-governed variety.

The state-led system in China features a powerful state that dominates economic governance. The Chinese economic reforms have supported the continuation of a strong state at the core along with the devolution of economic activities to regional levels and private enterprises (Nee, 1992). Politically, the unitary one-party political system of China limits the power of business organizations to resist state mandates. The state implements directive economic policies to establish institutional expectations and policy incentives for specific business activities (e.g., the consecutive five-year plans, the "go-out" policy, the "One Belt, One Road" policy, etc.), which may not necessarily reflect individual firms' commercial interests. The state-led system played an important role in the formation and development of BGs in China. BGs, or more specifically state-owned BGs, were established by the government during its SOE 
[Authors' final version]

reforms in the mid-1980s when the key focus was on achieving economies of scale and specialization (Keister, 2000). In the early 1990s, the Chinese government emphasized building the "highly competitive largest BGs" in its national economy to promote international competitiveness (Lee \& Kang, 2010: 219). State-led policy initiatives such as the "Strong-Strong Combination" (Lee \& Kang, 2010: 220) and "National Champions" (Guest \& Sutherland, 2010: 617) with strong financial backing have helped many Chinese firms, including BGs, enter the international stage and became globally competitive (Buckley, et al., 2018; Gaur, Ma \& Ding, 2018). As suggested by Ramamurti \& Hilleman (2017: 43-44), the main reason for the distinctive internationalization of Chinese firms is "the competence with which the Chinese government used the policy levers at its disposal...."Since the 2000s, different types of ownership structures have emerged and gained momentum. For instance, Lee and Kang (2010) report that the percent of privately owned BGs increased from 19 percent in 2000 to 44 percent (of 2,856 BGs) in 2007. Similarly, SOEs' dominance is contested and balanced by private businesses in the business domain (The Economist, 2012). In summary, the state maintains its influence across economic sectors via large SOEs (Huang, 2008; Lee, 2009) along with the selective diffusion of market principles that are attributable to ongoing privatization and China's integration into the global economy (Li et al., 2014; Lin \& Milhaupt, 2013). The vacillation of the state with respect to the relative importance of the various economic actors has been achieved by continuous policy changes (Huang, 2008). Under this state-led system, businesses in China, state-owned or private, are underpowered relative to the state and therefore cannot effectively influence, let alone challenge, the state's direction of the economy.

Under the overarching state-led nature of China's state capitalism, the interaction between the state and businesses in China is dynamic and complex. Since the 1980s, the Chinese state has "fixed its course to remake the economic institutions of state capitalism not by revolution but by reform" (Nee, 1992: 1). However, the reform process has been implemented unevenly across the country, which has led to substantial variations in the degree of marketization across subnational locations (Banalieva, Eddleston, \& Zellweger, 2015). As a result, the state's influence on the economy is subtler and more indirect in more marketized provinces than in those provinces whose local economy remains highly regulated and 
[Authors' final version]

dominated by SOEs. Moreover, the decentralization of the state's economic coordination also created different state-business dynamics between central and local levels. At the central level, the state focuses its influence on selected strategic industries with policy implications, whereas at the local level, pressured by social and economic responsibilities, local states remain deeply engaged with the economy and have invested interests across local businesses ( $\mathrm{Li}$ et al., 2014). However, the administrative and economic decentralization in China is not a linear process. Huang (2008: xvii) suggests that the state's strong coordination role in the economy has led to numerous underlying policy changes that have reversed experiments at the local level and afforded primacy to centrally owned and controlled SOEs and other private enterprises. Despite the differences between central and local levels and across subnational locations, one sustaining element of China's state capitalism is the unchallenged political position of the one-party state. As long as state-business interactions occur in a unitary political system, business organizations have limited active agency to resist institutional pressures from the state and fundamentally influence institutional processes. The power of the state and the lack of active agency of businesses are constant indications of China's state-led system.

In the case of India, by contrast, a co-governed system is achieved by the relative power balance between the state and business organizations. The Indian institutional environment is characterized by a less interruptive government that also supports private businesses in economic coordination (Kumar \& Chadha, 2009). Politically, India has a federal multiparty system. To solicit political support from multiple constituencies, successive Indian governments have had to align their economic policies with the needs of these constituencies, including big businesses (Kohli, 2006a, 2006b, 2007; Rodrick \& Subramanian, 2005). After its independence in 1947, similar to other developing economies, India relied on the principles of import-substitution industrialization for its economic development model. However, this policy was implemented through a combination of establishing SOEs and encouraging the formation of private BGs. Until the 1980s, India could be classified as a "fragmented-multiclass [state] ... where leaders need[ed] to worry about political support" (Kohli, 2004: 11) and simultaneously promote economic growth and redistributive objectives. Furthermore, "the relationship of the state to the private 
sector [was] more complex, ... sometimes cooperative but just as often conflictual” (Kohli, 2004: 14). Although formal economic reforms in India were initiated in 1991, state capitalism in India was transformed earlier in the mid-1980s (Kohli, 2006a, 2006b, 2007; Rodrick \& Subramanian, 2005). Successive Indian governments moved toward promoting economic growth over redistributing policy objectives. This transformation was implemented through a pro-private business orientation. According to Rodrick and Subramanian (2005: 195), a pro-market orientation "focuses on removing impediments to markets and aims to achieve through economic liberalization. It favors new entrants and consumers. A pro[-]business orientation, in contrast, focuses on raising the profitability of the established industrial and commercial establishments. It tends to favor incumbents and producers." Evidence suggests that India's state capitalism model is one where the state has deferred economic coordination to the private sector, while SOEs primarily operate in a few sectors, such as public utilities, banking and finance, and social sectors. For instance, the share of SOEs in manufacturing GDP decreased from 35.62\% in 1993 to $14.22 \%$ in 2006, and the share in utilities from $90.51 \%$ to $67.73 \%$ (Mishra, 2009). A variety of industrial policy reforms in the 1990s further removed constraints on the Indian private sector through de-licensing, opening sectors formerly reserved for the SOEs, and offering tax concessions (Kohli, 2006b). Accordingly, large firms (usually affiliated with BGs) continue to play a very powerful role in the economy, holding 70 percent of corporate sector assets in 2006 (Sarkar, 2010). Furthermore, unlike in China, where BGs were initially created by the state, Indian BGs are mainly family-owned, having maintained a highly concentrated ownership structure for decades. Some leading family BGs such as Tata and Birla were established in the second half of the $19^{\text {th }}$ century and have witnessed various phases of India's institutional development, from the colonial period of pre-independence to the economic liberalization since the 1990s, working alongside the government to sustain and expand their businesses. Under this co-governed economic system operating in a pluralist political context, business organizations can resist institutional pressures and even influence economic policy. Owing to their heft, arising from large scale and scope, BGs have been able to use their political power over policy domains for their own ends (Majumdar \& Sen, 2007). Sarkar (2010: 311) notes that some large BGs were able to 
[Authors' final version]

obtain state support and to "maneuver the government" to their advantage by obtaining a disproportionately high number of industrial licenses during the license raj period. Similarly, Kochanek (1996) reports that by actively participating in trade associations and extensively lobbying political parties, private businesses in India were able to resist and delay opening the Indian economy to inward foreign direct investment (FDI). Thus, in the co-governed state capitalist system in India, there is more of a symbiotic relationship between the state and business organizations, which ascribes active agency to businesses (especially big business) to shape policy decisions.

\section{HYPOTHESES}

\section{BG Affiliation and the Persistence of Superior Firm Performance}

BGs serve as an effective substitute governance structure for market institutions to ensure that internal business transactions are facilitated in the presence of external market failures (Chacar \& Vissa, 2005; Khanna \& Palepu, 1997). However, the advantages of BGs are not confined to market failures or institutional voids (Manikandan \& Ramachandran, 2015). For instance, through their internal markets, BGs contribute to their affiliates' competitiveness through economies of scope that maximize the utilization of value-adding assets, such as brands, technology, and information (Lamin, 2013). Thus, the literature has employed a variety of theoretical lenses, including market failures, transaction cost analysis, social networks, and the resource-based view, to explain the performance-enhancing benefits of BG affiliation (see Carney et al., 2011).

However, the literature remains divided as to whether competitive advantages arising from BG affiliation can help firms sustain their superior performance or whether such advantages will be outweighed by the associated governance and agency problems that may erode affiliated firms' superior performance (Chacar \& Vissa, 2005; Chari \& David, 2012; Chittoor et al., 2015; Estrin, Poukliakova, \& Shapiro, 2009; Gedajlovic \& Shapiro, 2002). Research suggests that the varied implications of BG affiliation for the persistence of the superior performance of an affiliated firm are due to different internal practices of BGs in allocating resources through their internal markets. Different internal resource allocation strategies have diverging effects on the persistence of the superior performance of affiliated 
firms in comparison to unaffiliated firms. While unaffiliated firms' performance persistence is mainly a function of their individual sustainable competitive advantages, the sustainability of BG affiliates' competitive advantages is subject to the group-level coordination of resource allocation. Relative to unaffiliated firms, BG affiliates may have higher persistence of superior performance if they are internally rewarded for their competitiveness by receiving prioritized resource support from the BG internal market to further sustain their competitive advantages. In an opposite scenario, relative to unaffiliated firms, BG affiliates may have lower persistence of superior performance if they are required to subsidize weaker members of the group and have their resources tunneled away through the BG internal market, undermining the sustainability of their competitive advantage. Accordingly, the observed difference between affiliated and unaffiliated firms' persistence of superior performance can be attributed to the BG affiliation effect, which depends on BG's internal resource allocation strategy. Prior studies point to two contrasting patterns for BG's internal resource allocation.

First, a safety-oriented internal coordination practice leads to a cross-subsidizing pattern of resource allocation among BG affiliates. Such resource allocation patterns respond to competitive pressure by offsetting survival threats to member firms (Gopalan et al., 2007; Lincoln et al., 1996). It can also allow BGs to tunnel funds away from profitable affiliates that would otherwise continue to perform competitively (Jia et al., 2013). As a result, relative to unaffiliated firms, the superior performance of affiliated firms is less persistent, with a cross-subsidizing pattern of resource allocation being institutionalized and implemented in BGs.

Second, a competitiveness-oriented internal coordination practice leads to the winner-picking pattern of BG resource allocation. Siegel and Choudhury (2012: 1796) show that BGs respond to competitive pressure more "honestly," suggesting that instead of propping up affiliates to survive a negative industry shock, BGs can cut back on scale to preserve profitable businesses. Estrin and colleagues (2009) conceptualize this competitiveness-oriented behavior of BGs where resources are allocated from weaker to stronger members as being consistent with what Cestone and Fumagalli (2005) termed winner-picking. Such group-level restructuring allows BGs to respond to intensifying external 
market competition in which they divest unrelated businesses while strengthening core ones (Ghemawat \& Khanna, 1998). Consequently, the more-competitive affiliates receive prioritized support from the BG, enhancing their performance persistence relative to unaffiliated firms.

These contrasting internal resource allocation mechanisms of cross-subsidizing and winnerpicking suggest that there is unlikely to be a universal BG affiliation effect. Indeed, prior empirical studies present mixed findings across country contexts, with BG affiliates showing both higher (e.g., Khanna \& Yafeh, 2005; Lin \& Milhaupt, 2013) and lower (e.g., Gopalan et al., 2007; Jia et al., 2013) levels of performance persistence in comparison to unaffiliated firms. Nevertheless, Khanna and Yafeh conclude that BGs tend to converge on their resource allocation practice within a country but differ systematically between countries and that "different group attributes cannot (easily) explain intercountry differences" (2005: 333). From an institutional perspective of state-business interaction, we argue that the type of state capitalism can explain intercountry differences in BGs' resource allocation patterns. The interaction between BG internal institutions and the type of external institutional environment will impact the average effect of BG affiliation on the persistence of superior firms. Moreover, key attributes of the focal affiliated firm, in particular the level of internationalization that distances the affiliate from its home state influence, can explain the within-country variation in the effect of BG affiliation on the persistence of superior firm performance. We elaborate on these predictions in more detail below.

\section{Divergence of the BG Effect between China and India}

In the state-led capitalist system in China, businesses are subject to direct and extensive institutional pressures from the state. Top-down changes to directive economic policies can increase survival pressure for organizations, whereas businesses are unlikely to influence or challenge such policy changes (Huang, 2008; Li et al., 2014; Lin \& Milhaupt, 2013). As the state controls critical economic inputs and has the executive power to allocate them between state-owned and private sectors as dual engines of economic growth, it increases businesses' resource dependence on the state. High resource dependence, in turn, pressures businesses to conform to external institutional expectations (Oliver, 1991). Accordingly, 
Chinese BGs must maintain legitimacy with the state by conforming and adapting to policy changes to compete for state-controlled resources.

With a dominating state that is focused on developmental objectives (Witt \& Redding, 2013), the Chinese government's economic policies are devised to replace missing market-coordination mechanisms from a competitive marketplace (Huang, 2008; Li et al., 2014), bestowing legitimacy on businesses with compatible practices that conform to the competitiveness-building expectations of the state. For BGs, the consistency between the resource allocation principles of their internal market and that of the state's external economy coordination reflects the compliance of BG practices with institutional expectations. Consistent with the state's resource allocation principle in support of its developmental goals (e.g., upgrading industries and promoting national champions for global competition), BGs can induce competitive mechanisms among affiliated firms to mimic market competition (Estrin et al., 2009). With the state allocating critical resources to enhance the competitiveness of the general economy, BGs are incentivized to strategically allocate internal resources to support affiliates with the potential to achieve future success, as evidenced by their current profitability, instead of supporting low-performing affiliates that have proven uncompetitive and that are also less likely to obtain legitimacy from the state. Consequently, BGs are likely to internally institutionalize the winner-picking pattern of resource allocation to shift resources toward (rather than away from) high-performing affiliates. ${ }^{5}$

This winner-picking pattern of internal resource allocation, although by no means the only possibility for all Chinese BGs, is likely to dominate China's state capitalist system despite the institutional diversity and complexity internal to China discussed above. The central and local states in China are not monolithic in respect to their preferences. However, the general trend of market-oriented economic reform is strong and persistent across the country, evidenced by the substantial effort toward the privatization and marketization of SOEs at both the central and local levels (Li, Cui, \& Lu, 2017) and the continuous development of market-supporting institutions across all provinces (Fan, Wang, \& Zhu, 2012). Moreover, by attracting inward FDI, local states can secure alternative sources of tax revenue and employment opportunities, reducing their incentives for propping up failing local businesses. Therefore, 
other than a few strategic industries (e.g., steel manufacturing, critical infrastructure) where the state needs to manage the political and social consequences of marketization, the state logic in China promotes market competition, granting legitimacy to winner-picking rather than to the cross-subsidizing patterns of BG internal resource allocation.

In the co-governed state capitalist system of India, the state's acceptance of the private sector as the primary engine of economic growth, combined with its pluralistic political system, reduces the likelihood of frequent and directive policy changes that interfere with business practices. In this type of state capitalism, the state establishes the general regulatory frameworks and coordinates the economy at arm's length (Khanna \& Yafeh, 2007). With a pro-business orientation, the state defers economic coordination to the private sector while making economic inputs available to incumbents to support their growth (Rodrick \& Subramanian, 2005). Businesses in such an institutional environment are not strongly pressured to conform to external institutional expectations; indeed, they are empowered to resist or even manipulate institutional pressures (Kochanek, 1996). Thus, BGs build and maintain their legitimacy as a market-substituting governance structure not by conforming to external institutional expectations (as rule takers) but by expanding their market power and social and economic influences (as rule makers) to negotiate with the state for legitimacy. For instance, in the case of a large Indian business group, The Economist (2016a) suggests that "Tata's heft has indeed been useful in the past for entering new markets. Size helped it raise capital when it was scarce and to lobby government."

Research shows that Indian BGs are particularly capable of retaining their competitiveness by efficiently using internal capital, labor, and product markets and influencing market development, all of which have led to their long-term dominant position in the Indian economy (Khanna \& Yafeh, 2007). The viability and benefits of sustaining internally institutionalized practices motivate BGs to maintain the scale and scope of their internal markets; thus, the success of an individual affiliate is frequently superseded by group objectives. Accordingly, BGs will utilize their group structure as a cross-subsidizing mechanism in which resources are allocated from successful affiliates to support other/weaker members to sustain the group's overall scale and scope (Gopalan et al., 2007) and maximize rent seeking 
opportunities (see Alfaro \& Chari, 2014; Majumdar \& Sen, 2007). The co-governed state capitalist system also affords Indian BGs greater agency to pursue self-interest while interacting with external stakeholders. Cross-subsidizing is an effective tool for securing family control and tunneling profits in BGs, and as a result, cross-subsidization is prevalent among India BGs. For example, recent reports on one of the most dominant BGs in India, the Tata group, suggest that only two or three affiliates are profitable and continue to support the majority of low-performing affiliates (The Economist, 2016a; 2016b). Institutionalizing this cross-subsidizing pattern of internal resource allocation moves resources away from high-performing affiliates, diminishing firms' ability to maintain superior performance.

In summary, although BG affiliation renders certain resource and synergy advantages to member firms that may benefit from their performance (Chang \& Hong, 2000; Khanna \& Rivkin, 2001), we argue that the effect of BG affiliation on the persistence of superior performance varies depending on the resource allocation mechanism internal to a BG that is compatible with its external institutional context. Given the distinct types of state capitalist systems between China and India, Chinese BGs obtain legitimacy through compliance with the state, whereas Indian BGs do so through negotiation with the state. In general, Chinese BGs signal legitimacy to the state by aligning with its developmental economic policies, but not by maintaining or expanding scale and scope. In practice, they tend to be more active in competitive restructuring and prioritizing resources, which requires a winner-picking pattern of internal resource allocation. Indian BGs, by contrast, tend to promote themselves as business elites that also possess considerable social and political influence in order to enhance their power over the government to influence policy-making. They do so by maintaining or expanding scale, horizontally diversifying into various sectors of the economy, and potentially building their corporate/BG brand to supersede national identity. This requires a cross-subsidizing pattern of internal resource allocation. Due to these different internal resource allocation emphases (not exclusive use) by Chinese and India BGs, we hypothesize:

Hypothesis 1: The effect of BG affiliation on the persistence of superior firm performance is likely to be higher in China's state-led system than in India's co-governed system.

\section{Firm Internationalization and Convergence of the BG Effect}


While the above argument applies to BGs and their affiliates when they operate under the dynamics of state-business interaction shaped by the home institutional environment, what about affiliated firms that operate outside their home markets (i.e., internationalized firms)? Following the logic that BG internal resource allocation serves as a legitimation strategy of BGs when interacting with the home-country state, we argue that as affiliated firms are exposed to competitive and institutional pressures abroad, both the winner-picking and cross-subsidizing strategies will become less impactful on their performance persistence. In other words, contact with new market and institutional environments abroad reduces the home-country effects. Consequently, the diverging BG affiliation effect on performance persistence in different state capitalism environments, as hypothesized above, will converge as the focal affiliates internationalize.

For Chinese BG affiliates, the resource gains enabled by winner-picking are less effective for sustaining or enhancing competitiveness in foreign markets, where key competitive resources may differ from those in the home country. While winner-picking may align firm practices with the expectation of a dominating state at home and thus attain home institutional legitimacy, it does not automatically provide the firm with access to institutional support or resources in foreign markets that are more relevant for competitive advantages in those markets. Research suggests that as the rules of the game change, the productivity of previously accumulated competitive resources will diminish (Chari \& David, 2012; Peng, 2003). As firms internationalize, they are exposed to new sets of rules that can have implications on their existing resource advantages (e.g., Marano, Tashman \& Kostova, 2017). For Chinese BGs, various resource gains from winner-picking will become less impactful on their high-performing affiliates' performance persistence when they internationalize. Specifically, in terms of financial resources, profit redistribution from domestic to international affiliates faces many home-country regulatory constraints. China is vigilant about outward FDI being abused as a channel of capital flight by both state-owned and private corporations (Cui \& Jiang, 2012) and has exerted extensive reporting and monitoring requirements in outward FDI administrative procedures. These home-country rules on internationalizing Chinese firms increase the cost of resource allocation toward these firms. In terms of human resources, while BGs may 
pool their skilled labor and domestic social capital to support their winner affiliates, these resources are unlikely to solve the human resource bottleneck for Chinese firms' international success, most noticeably the "lack of global experience, managerial competence, and professional expertise" (Luo \& Tung, 2007: 482). Similarly, other types of BG resource advantages, such as prioritized use of land and governmentgranted privileges (tax concessions, government procurement contracts, etc.) are also largely tied to domestic operations. As a result, while winner-picking grants high-performing Chinese BG affiliates more resource advantages to sustain their performance than unaffiliated firms, these advantages are less effective outside the home-country market, thus causing the positive BG affiliation effect on superior performance persistence to weaken for internationalized affiliates.

On the other hand, affiliates of Indian BGs will be less subject to cross-subsidizing when they internationalize. The primary motivation for cross-subsidizing is to maintain and expand the scale and scope of a BG's internal market so that the BG can ensure its social and economic dominance to legitimize its self-serving practices. To cross-subsidize weaker members of the group, BGs will compromise high-performing affiliates' ability to sustain superior performance (Gopalan et al., 2007). Nonetheless, high-performing affiliates are incentivized to comply with the BG's central coordination sustaining the "coinsurance" scheme (Jia et al., 2013: 2295) because they are resource-dependent on the group and/or are closely controlled by the BG through family ties. However, these resource and relational linkages are likely to weaken as the affiliates internationalize. First, the internationalization mode of many Indian firms (especially those entailing FDI) is through alliances with foreign firms as well as through foreign acquisitions. In such internationalization modes, the affiliated firms' resource dependency on the BG reduces as they increasingly rely on linkages with organizations abroad to fulfill their key strategic objectives of seeking foreign assets (Gubbi, Aulakh, Ray, Sarkar, \& Chittoor, 2010). Second, management of overseas operations typically requires skills that may not be available among BG family members and therefore require BGs to transfer considerable decision-making power to outside professionals (Bhaumik, Driffield, \& Pal, 2010). Consequently, compared with domestic affiliates, internationalized affiliates are less connected with the rest of the group through managerial ties, which 
[Authors' final version]

serve as an important control mechanism for BG central coordination. In addition to the changes in bonding with parent and new partnerships, internationalization also exposes Indian firms to the "external scrutiny of regulators, investors, creditors, and credit-rating agencies" (Bhaumik et al., 2010: 440) as they become more dependent on these external stakeholders for capital and legitimacy to operate abroad. With this heightened exposure, BG cross-subsidizing by expropriating high-performing internationalized affiliates will be subject to greater regulatory penalties and reputational damage, especially when they operate in foreign markets with more stringent corporate governance practices. Overall, as Indian BG affiliates internationalize, both their internal incentives and the external feasibility of cross-subsidizing decline, weakening the negative BG affiliation effect on the persistence of their superior performance. In summary, we argue that both the winner-picking and cross-subsidizing resource allocation practices of BGs become less effective as affiliated firms internationalize despite the contrasting institutional difference in their country of origin. As such, the divergence of BGs' resource allocation practices across different types of state capitalism will weaken as affiliated firms leave the home institutional environment, leading to a convergence of the BG affiliation effect on firms' persistence of superior performance. Accordingly, we hypothesize:

Hypothesis 2: The divergence of the BG affiliation effect on the persistence of superior firm performance between China and India (as stated in Hypothesis 1) weakens as firms internationalize.

\section{METHODS}

\section{Sample}

Based on our conceptual framework contrasting the institutional environments of China and India, our empirical analysis focuses on these two large emerging economies. To examine the effect of BG affiliation on the persistence of firms' superior performance, we draw our research sample from publicly listed manufacturing firms in China and India with market capitalizations of greater than USD50 million. We choose this sampling approach because such firms provide a viable sample to compare the internationalization and persistence of superior performance of Chinese and India BG firms, and this 
[Authors' final version]

approach enables us to obtain more available and reliable data over a six-year span from 2005 to 2010. Based on the Osiris database, a commercially available database used in prior studies in the Chinese (Cui \& Jiang, 2012) and Indian (Bhaumik et al., 2010) contexts, 641 Chinese firms and 512 Indian firms were identified by our sampling criteria. Table 1 presents descriptive information for our sample. More than $40 \%$ of Chinese firms and $60 \%$ of Indian firms were affiliated with a BG during our sampling period. The total market capitalization of the sample firms represents a significant proportion of the applicable national GDP of both China (11.72\%) and India (21.47\%).

[Place Table 1 about here]

Our panel dataset of sample firms for the 2005-2010 period comes from several sources of BGand firm-level data. Data related to firm financials and internationalization are obtained from the Osiris database, whereas firms' BG affiliation and other BG-related data are from the China Large Business Group Yearbook and the Osiris database for Chinese firms (Guest \& Sutherland, 2010; Singh \& Gaur, 2009) and from the Prowess database for Indian firms (Chacar \& Vissa, 2005; Gubbi et al., 2010). These data resources are further supplemented and triangulated with information from firms' annual reports and websites. Lagged effects must be incorporated into an examination of firms' performance persistence (see Chacar, Newburry, \& Vissa, 2010; Chacar \& Vissa, 2005), which reduces our panel length to five years. Since our study focuses on the persistence of superior firm performance, after dropping firms whose profitability is equal or below the industry average of their country (see detailed explanation in the later section), we retain an unbalanced panel of 1,875 observations, including 1,125 and 750 observations for Chinese and Indian firms, respectively. ${ }^{6}$ Finally, all the continuous variables were winsorized at the $1 \%$ level to mitigate the influence of outliers.

\section{Models and the Dependent Variable}

Performance persistence reflects “the percentage of a firm's previous year performance remaining in the present period" (Chacar et al., 2010: 1127). In line with previous studies on performance persistence (e.g., Chari \& David, 2012; Choi \& Wang, 2009), we adopt a dynamic first-order autoregressive model to test the persistence of firms' superior performance in China and India. The following models are generated: 
Model for Hypothesis 1: $P_{j, t}=\alpha_{j}+\beta_{1} x_{j, t-1}+\beta_{2} P_{j, t-1}+\beta_{3} B G_{j, t-1}+\beta_{4} B G_{j, t-1} \times P_{j, t-1}+\beta_{5}$ China $_{j}$

$$
+\beta_{6} \text { China }_{j} \times B G_{j, t-1}+\beta_{7} \text { China }_{j} \times P_{j, t-1}+\beta_{8} \text { China }_{j} \times B G_{j, t-1} \times P_{j, t-1}+\varepsilon_{j, t}
$$

Models for Hypothesis 2 (split sample of domestic/international firms): $P_{j, t}=\alpha_{j}+\beta_{1} x_{j, t-1}+\beta_{2} P_{j, t-}$

$$
\begin{aligned}
& { }_{1}+\beta_{3} B G_{j, t-1}+\beta_{4} B G_{j, t-1} \times P_{j, t-1}+\beta_{5} \text { China }_{j}+\beta_{6} \text { China }_{j} \times B G_{j, t-1}+\beta_{7} \text { China }_{j} \times P_{j, t-1} \\
& +\beta_{8} \text { China }_{j} \times B G_{j, t-1} \times P_{j, t-1}+\varepsilon_{j, t}
\end{aligned}
$$

Models for Hypothesis 2 (China/India split sample): $P_{j, t}=\alpha_{j}+\beta_{1} x_{j, t-1}+\beta_{2} P_{j, t-1}+\beta_{3} B G_{j, t-1}+\beta_{4} B G_{j, t-}$

$$
{ }_{1} \times P_{j, t-1}+\beta_{5} I N T_{j, t-1}+\beta_{6} I N T_{j, t-1} \times B G_{j, t-1}+\beta_{7} I N T_{j, t-1} \times P_{j, t-1}+\beta_{8} I N T_{j, t-1} \times B G_{j, t-1} \times P_{j, t-1}+\varepsilon_{j, t}
$$

In the equations above, $P$ denotes the performance of a firm; subscripts $j$ and $t$ represent the firm and year, respectively; $P_{j, t-1}$ denotes the performance of the firm at time $t-1 ; x$ is a vector of control variables (discussed later in this section); and $B G$, China, and INT are independent variables that measure the firm's BG affiliation (BG), country dummy (China), and internationalization (INT).

Following prior studies on performance persistence (Chacar \& Vissa, 2005; Chari \& David, 2012), we use firm-specific rent (FSR), measured as the country-industry-year-adjusted return on assets (ROA) as our dependent variable. This measure removes country, industry, and year effects caused by country-level differences in economic conditions and accounting practices, as well as industry-level (based on 3-digit NAICS codes) differences among firms for each country and year (Chacar \& Vissa, 2005). To identify firms with superior performance, we followed Chacar and Vissa's (2005) approach by selecting firms whose FSR value is greater than the average FSR in their country. This selection criterion yields a reduced subsample of 1,875 firm-year observations, as mentioned earlier. Alternative to this measure, following some prior studies (Estrin et al., 2009; Khanna \& Palepu, 2000), we also use unadjusted ROA as the dependent variable in a range of robustness tests, which returned consistent results.

\section{Independent and Control Variables}

Consistent with prior BG research (e.g., Khanna \& Palepu, 2000; Khanna \& Yafeh, 2005; Singh \& Gaur, 2009), we used the dummy variable $B G$ to capture a firm's affiliation with a BG. This variable takes a 
[Authors' final version]

value of " 1 " if a firm is affiliated with a BG and " 0 " otherwise. For robustness tests, we used BG ownership as an alternative measure of BG affiliation following some prior studies (Carney et al., 2009). BG ownership is calculated as the total percentage of shares held by a BG and its affiliates in the focal firm. Robustness tests using this alternative measure returned consistent results.

China is a dummy variable that distinguishes the country of origin of our sample firms, with a value of " 1 " assigned to Chinese firms and " 0 " assigned to Indian firms. This dummy variable approach is both theoretically consistent with our research objective and empirically feasible in our research context. First, our theoretical focus is to capture the difference in the role of the state between China and India. The nature of this difference determines the type of measure we use. Comparative institutionalism research suggests that cross-country institutional variations are better captured by the difference in type, rather than in degree, because individual elements of a country's institutional environment (such as the role of the state) do not vary independently from other institutional elements but evolve as an internally consistent configuration in a path-dependent manner (Hall \& Soskice, 2001; Jackson \& Deeg, 2008). Consistent with this logic, political science research has a tradition of distinguishing the role of the state by typologies (e.g., Carney \& Witt, 2014; Whitley, 2003; Zhang \& Whitley, 2013) rather than by any quantitative scale. Accordingly, the role of the state between China and India represents two distinct types of state capitalism, which can be distinguished by a dummy variable. Second, using a dummy variable to capture between-country institutional differences follows the approach of prior empirical studies (Chacar \& Vissa, 2005; Lin, Peng, Yang, \& Sun, 2009). These studies show that when other significant betweencountry differences are adequately accounted for in statistical analyses, a dummy variable can effectively capture the between-country difference in the institutional dimension of interest. In our analyses, we control for an extensive range of BG- and firm-level factors that may be correlated with country-level economic and institutional differences between China and India. These control variables are discussed below in more detail. While acknowledging the inherent empirical limitations of cross-national studies and the related methodological hurdles of isolating country-level effects, we believe that, similar to other recent comparative studies in international business (and more specifically related to BGs) (e.g., Chang, 
Chung \& Mahmood, 2006; Chacar \& Vissa, 2005), by incorporating extensive controls in our analyses, our results provide evidence of the differences in state capitalisms as a plausible factor influencing organizational strategies.

Firm internationalization (INT) is measured by the total number of foreign subsidiaries of the focal firm to capture its degree of internalization activity in the form of FDI, which is the highest commitment level among all foreign market entry modes (Lien et al., 2005). This measure reflects the structural dimension of firm internationalization (Sullivan, 1994). Alternatively, we measure the performance dimension of firm internationalization by using the ratio of a firm's foreign sales to its total sales (Sullivan, 1994), which has been widely used in the extant literature to measure firms' degree of internationalization (Brouthers \& Dikova, 2010; Tallman \& Li, 1996). Both measures returned largely consistent results.

We include several BG- and firm-level variables to control for firms' performance differences. For BG-affiliated firms, $B G$ size is measured by the natural logarithm of the total assets (in thousands of US dollars) of the BG with which a focal firm is affiliated. Similarly, BG diversification is measured by the total number of SIC 2-digit equivalent industries in which the BG operates (Khanna \& Palepu, 2000). Adding these BG-level control variables is necessary to rule out potential confounding effects, thus allowing us to identify the hypothesized country effect after accounting for the major systematic differences between BGs in the two countries.

At the firm level, firm size is measured by the natural logarithm of a firm's total assets (in thousands of US dollars), and firm age is measured by the number of years that have elapsed since a firm was incorporated. Sales growth represents a firm's non-financial performance and is measured as the annual increase in sales. Leverage is a debt-asset ratio that assesses a company's ability to obtain external funding. We also control for a firm's market power because the firm's standing in its industry may affect its performance. Following Gubbi et al.'s (2015) calculation of market power, we calculate a ratio of a firm's previous market share (i.e., total sales in year $_{t-1}$ ) relative to that of its industry leader to measure the firm's market power. The range of this variable is from " 0 " to " 1 ", where " 1 " means the focal firm is the 
[Authors' final version]

industry leader. Moreover, in emerging economies, government ownership of firms can play an important role in resource allocation and performance expectations (Musacchio et al., 2015). In China, the BG as an organizational structure was first introduced in SOEs, and large Chinese BGs tend to be owned by the state (Lee \& Kang, 2010). To tease out this effect, we include state as a dummy variable that is coded "1" if a firm is affiliated with the government through state ownership and " 0 " otherwise (Dastidar, Fisman, \& Khanna, 2008). We also include the interaction term State $\times F S R_{t-1}$ to control for any state ownership influence on the performance persistence of the firms.

Furthermore, to control for self-selection into listing, especially in China, where listing prior to 2001 was more influenced by the government (Jeffries, 2006), we add two control variables, a firm's IPO age and state financial institutional (SFI) ownership, into all our models. IPO age is measured by the number of years that have elapsed since a firm listed on a stock exchange in its country, and SFI ownership is measured by the percentage of ownership (within the top ten) held by state-owned financial institutions. In addition, large individual shareholders also play an important role in the functioning of firms in emerging economies. We incorporate individual (IND) ownership as a control that is measured as the percentage of ownership (within the top ten) held by the firm's individual and family owners (Carney, Shapiro, \& Tang, 2009). We also include foreign (FOR) ownership of the focal firm to control for possible differences in corporate governance quality in the Chinese and Indian firms. Following Hu and Cui (2014), FOR ownership is measured as the percentage of ownership (within the top ten) held by the firm's foreign owners. Finally, independent, moderating, and control variables are lagged by one year in our model analysis both to ensure a more accurate examination of the framework and to mitigate potential endogeneity problems.

\section{Analyses}

This study uses panel data consisting of both cross-sectional and time-series data on the sample firms for the period of 2005-2010. We employ dynamic panel models because one of the study's independent variables is a lagged dependent variable (specifically, previous year performance), implying that such lagged dependent variable $P_{j, t-1}$ is correlated with the error term $\varepsilon_{j, t}$ (Baltagi, 1995). Common estimation 
[Authors' final version]

techniques such as fixed- or random-effects or least squares dummy variable approaches are biased because of the correlation between the estimation models and the lagged dependent variable (Nickell, 1981). In line with prior studies on performance persistence (e.g., Chacar \& Vissa, 2005; Chari \& David, 2012; Choi \& Wang, 2009), we employ Nickell's method of bias correction for dynamic panel models (Phillips \& Sul, 2007).

To determine the appropriate empirical model, we first conduct a Breusch-Pagan Lagrange Multiplier test. The results from this test reveal that the data contain unobserved individual effects, indicating that panel models instead of pooled ordinary least squares models should be used. Furthermore, we perform the Hausman test, which returns results in favor of random-effects models over fixed-effects models. Random-effects models are appropriate for our analysis because most of the predictors in our models, such as the country dummy and the BG affiliation dummy, are time-invariant binary variables. In addition, we perform robustness tests using fixed-effect models and Arrellano-Bond dynamic panel models, which are discussed in a later section.

\section{RESULTS}

\section{Descriptive Statistics}

Table 2 reports the descriptive statistics and correlation matrices of the selected superior performers for the full sample (Panel A), the Chinese subsample (Panel B), and the Indian subsample (Panel C). This table reveals that the examined Chinese firms show a similar level of superior firm performance (in terms of FSR and FSR $\mathrm{F}_{\mathrm{t}-1}$ ) to the Indian firms. Although the Chinese firms are generally younger than their Indian counterparts, their average IPO age is slightly older than that of the Indian firms. Furthermore, China has a higher percentage of government-affiliated firms than India, whereas India, on average, has a much higher percentage of firms with individual/family ownership than China. Further, the average ownership of both the state-owned financial institutions and foreign owners is higher in the Indian firms than in the Chinese firms. The degree of internationalization measured by the number of foreign subsidiaries is also higher in the Indian firms than in the Chinese firms. As expected, the current and oneyear-lagged FSR measures are highly correlated, indicating the continuation of firms' performance level 
over time. We centered the independent and moderating variables for the interaction terms, and our collinearity diagnostics indicate that the variance inflation factors (VIF) of the examined variables are all less than 7 , and the average VIF is 2.75 , suggesting that multicollinearity is not a concern in the analysis.

[Place Table 2 about here]

\section{Hypotheses Testing}

We test the hypotheses in a series of random-effect dynamic panel models (Table 3). Model 1 includes all the control variables and the baseline model. We find positive and significant coefficients for the lagged performance variable $\left(\mathrm{FSR}_{\mathrm{t}-1}\right)$ and the interaction term between $\mathrm{BG}$ and lagged performance $(\mathrm{b}=0.10$; $p=0.014$ ), suggesting that performance persistence (the influence of the previous year's performance on present performance) is strengthened by BG affiliation.

[Place Table 3 about here]

Hypothesis 1 posits that due to the different types of state capitalism, the BG effect on a firm's persistence of superior performance is more pronounced in China than in India. This hypothesis is tested in Model 2 of Table 3, which includes the three-way interaction of BG affiliation, lagged performance, and country dummy. The coefficient of this three-way interaction term is positive and significant $(b=2.04$; $p=0.002$ ), suggesting that the BG effect on performance persistence is significantly higher in China than in India. Therefore, Hypothesis 1 is supported. To examine the effect sizes, we plot the three-way interaction effects ${ }^{7}$ and follow Dawson and Richter (2006) to perform slope difference tests between each pair of slopes. As the slopes (namely, the relationship between past and current performance) represent the levels of performance persistence of various groups of firms, we calculate the effect sizes related to our hypotheses based on the slope differences. We find that BG-affiliated Chinese firms have a performance persistent slope that is 5.5 times that of unaffiliated Chinese firms, and this slope difference is significant ( 2.602 vs. $0.475, \mathrm{t}=2.799, p=0.005)$. However, $\mathrm{BG}$-affiliated Indian firms are no more persistent than unaffiliated Indian firms, as the slope difference is non-significant $(\mathrm{t}=1.116, p=0.265)$. Accordingly, the BG effect is higher in China, where the BG effect size is $450 \%$, than in India, where the BG effect is not statistically significant. This effect size differential further supports our Hypothesis 1. 
Hypothesis 2 predicts that the country effect will reduce as firms internationalize, leading to a convergence of BG effects on firm's persistence of superior performance between China and India. We test this hypothesis through two sets of split sample random-effect dynamic panel models. In the first set, we compare domestic firms and internationalized firms, for which the results are reported in Models 3 and 4 , respectively. If internationalization weakens the country effect, we expect to see a smaller and less significant three-way interaction between BG affiliation, lagged performance, and the country dummy in the internationalized firm subsample than in the domestic firm subsample. Model 3 (the domestic firm subsample) shows that the three-way interaction remains positive and significant $(b=3.34 ; p=0.000)$, indicating that the country influence that differentiates BG affiliation effect on performance persistence is strong among domestic firms. Model 4 (the international firms subsample), however, returns a nonsignificant three-way interaction $(b=-0.53, p=0.733)$, showing that when firms internationalized, the country influence diminishes. Furthermore, we conduct a z-score difference test on the coefficients of the interaction term between Models 3 and 4. The test statistic (Z-score) is 2.290, which is significant ( $p=0.022)$, indicating that internationalization significantly reduces the country effect. All these results support Hypothesis 2.

In a second set of split sample tests, we compare Chinese and Indian firms, and the results are reported in Models 5 and 6. If our convergence prediction holds, we expect to see that internationalization weakens the BG effect in the Chinese subsample but strengthens the BG effect in the Indian subsample. Model 5 (the Chinese firms subsample) shows that the three-way interaction of BG affiliation, lagged performance, and internationalization is negative and marginally significant $(\mathrm{b}=-0.16 ; p=0.086)$, whereas Model 6 (the Indian firms subsample) shows that this three-way interaction is positive and significant $(\mathrm{b}=0.09 ; p=0.036)$. These results are consistent with our expectation about the convergence effect, thus providing further support to Hypothesis 2. We plot the three-way interactions of these two split sample tests to examine the effect sizes ${ }^{8}$. For the Chinese firm subsample, when firms are internationalized, BG affiliation does not make the firms' superior performance any more persistent, as the slope difference between affiliated and unaffiliated firms is non-significant $(\mathrm{t}=-0.159, p=0.873)$. For Chinese firms that are 
not internationalized, BG affiliation makes firms $81 \%$ more (slope for affiliated $=0.533$, slope for unaffiliated $=0.294)$ persistent than unaffiliated firms, as this slope difference is significant $(t=29.426$, $p=0.000$ ). Overall, the slope differences show that once firms are highly internationalized, the positive effect of BG affiliation on Chinese firms' persistence of superior performance disappears. For the Indian firm subsample, when firms are not internationalized, BG affiliation makes firms $23 \%$ less (slope for affiliated $=0.253$, slope for unaffiliated $=0.328$ ) persistent than unaffiliated firms, as the slope difference is negative and significant $(\mathrm{t}=-2.153, p=0.032)$, indicating the consequence of the cross-subsidizing behaviors of BGs in their domestic context. When Indian firms are internationalized, the negative effect of BG affiliation on performance persistence disappears, as the slope difference between affiliated and unaffiliated firms is non-significant $(\mathrm{t}=0.984 ; p=0.325)$. Combining the above effect size evidence, we conclude that internationalization weakens both the positive BG effect for Chinese firms and the negative BG effect for Indian firms, resulting in a convergence of BG effects between the two countries. These additional finding further support Hypothesis 2.

\section{Robustness and Supplementary Tests}

Subsample of privately owned (non-SOEs) listed firms only. To further test our theoretical argument on the types of state capitalism by removing any potential confounding effects between state ownership and the role of the state in influencing state-business relationships, we re-estimated the models in their entirety in a subsample of organically developed privately owned listed firms with superior firm performance. We examined this group of firms because a relatively large number of firms in China are state-owned, so to test the robustness of our results, we want to remove any potential effects that are caused by direct state ownership. Further, since some Chinese privately owned listed firms were transformed from previous SOEs, we also excluded such private firms from our subsample. As a result, we obtained a subsample of organically developed privately owned listed firms in China and India, and the sample size for China $(\mathrm{N}=295)$ is much smaller than that of India $(\mathrm{N}=654)$. Model 2 in Table 4 reports that the positive effect of $\mathrm{BG}$ affiliation on superior performance persistence is stronger in the Chinese firms than in their Indian counterparts. Models 3 and 4 show that the moderating effect of state capitalism 
[Authors' final version]

(as stated in Hypothesis 1) is weaker for internationalized firms than for purely domestic firms; Models 5 and 6 show that the moderating effect of firm internationalization on BGs' performance persistence effect is weakened in China but strengthened in India. Therefore, these findings provide strong support for the hypotheses, leading us to conclude that our original results in Table 3 are robust.

[Place Table 4 about here]

Resource allocation mechanisms. To further test the theoretical mechanisms of contrasting resource allocation arrangements within BGs, we utilized some intermediate outcome variables substantiating these mechanisms, which in turn influenced the performance persistence of Chinese and Indian firms. First, we examined the long-term solvency capability of a firm, measured by the firm's longterm debt over its current assets (Gulati \& Westphal, 1999). Long-term solvency indicates a firm's "ability to cover debt obligations in the long run" (Gryglewicz, 2011: 366), which is particularly relevant to our study, as it examines firms' capability to maintain superior financial performance over time. It is also regarded as an important indicator for a firm's cash flow policies, such as demand for corporate liquidity (Gryglewicz, 2011), or for making resource allocation decisions within a business group (Khanna \& Rivkin, 2001). Therefore, we focus on the solvency capability to examine the effects of firms' past performance and their interactions with BG affiliation in China and India. Results are reported in Table 5. Model 1 shows that when a firm performs well, its solvency capability increases, and Model 2 shows that this increase is greater for BG firms than for independent firms. Model 3 shows that this BG effect is greater for Chinese firms than their Indian counterparts, which supports our argument that resource injection such as net income or reduced debt by BGs into their high-performing affiliates is stronger in China than in India. The results of split-country subsamples show that the solvency of Chinese BG firms (Model 4) significantly increased when they performed well, whereas the Indian BG firms' (Model 5) solvency decreased when they performed well. This finding provides further support for our winner-picking and cross-subsidizing resource allocation arguments for China and India, respectively.

[Place Table 5 about here] 
Second, to more explicitly test direct resource allocation within BGs, we conducted two supplementary analyses. First, by following Lincoln et al.'s (1996) research on Japanese BG firms, we identified two cross-subsidization ties that are particularly relevant to our study: debt tie (i.e., net outstanding borrowing from the BG) and equity tie (i.e., ownership held by the BG) between the focal firm and its BG. As Lincoln and colleagues point out, debt tie indicates direct economic transactions with the group while equity tie shows the BG's control relations "that are superimposed on the network of business dealing but do not entirely conform to it" (1996: 75). ${ }^{9}$ Through debt financing and equity control, these cross-subsidization ties enable the BG to realign its affiliates' resources and prospects to its interests. Similarly, Jia et al. (2013) also identify loan-based related party transactions as a key mechanism by which BGs channel financial resources from high-performing affiliates to subsidize other affiliates, creating debt ties between the affiliates and the BG controller. Carney et al. (2009) highlight that BG affiliates vary in the degree to which they are connected to the group, which results in different directions of resource flows in the BG for tightly coupled and loosely coupled affiliates. They capture this "hierarchical aspect of business group structure" that directs BG internal resource flow using affiliate's equity tie with the BG, namely the percentage of ownership in an affiliate held by the BG (Carney et al., 2009: 172). Thus, following Lincoln et al.'s (1996) approach, we used these two cross-subsidization ties to separately regress on country-industry-year-adjusted ROA. Model 1 of Table 6 shows that debt tie strengthens the performance persistence of BG affiliates, thus suggesting there is resource allocation within BGs. Similarly, Model 4 also finds that equity tie strengthens the performance persistence of BG affiliates, which is consistent with the finding for the debt tie. Furthermore, the debt tie in the Chinese and Indian subsamples (Models 2 and 3) indicates that there is a winner-picking resource allocation effect in BG firms in China, whereas a cross-subsidizing resource allocation strategy is practiced in BG firms in India. Similarly, we also find such effects in the equity tie in the Chinese and Indian subsamples (see Models 4 and 5).

Second, we used the debt tie as the dependent variable to more precisely examine the capital injection the focal firm received from its BG based on its past performance. Using the subsample of BG- 
[Authors' final version]

affiliated firms, Model 1 of Table 7 shows that BG affiliates generally receive more capital injections from their BGs when they perform well. Model 2 shows that such capital injections are greater for Chinese BG firms than Indian BG firms. The country samples in Model 3 (Chinese subsample) and Model 4 (Indian subsample) also provide similar findings. Therefore, the results in Table 7 also support our argument that resource injection by BGs into high-performing affiliate(s) is much stronger in China than in India.

[Place Tables 6 and 7 about here]

Tests using alternative measures of key variables. We conducted several other robustness tests using alternative measures and techniques. First, we used alternative dependent and independent variables that were used in prior studies to re-estimate all the hypotheses. We employed $R O A$ as the alternative dependent variable for firm performance (Estrin et al., 2009; Khanna \& Palepu, 2000), BG ownership (an alternative variable for BG dummy) to measure the combined shareholding of a BG (promoter) in its affiliated firms (Bhaumik et al., 2010; Carney et al., 2009), and the ratio of a firm's foreign sales to its total sales as an alternative variable for INT, which has been widely used in the extant literature to measure firms' degree of internationalization (Brouthers \& Dikova, 2010; Tallman \& Li, 1996) in rerunning all the models using fixed-effect models (suggested by the Hausman test). We find similar results to the original results reported in Table 3. Second, following Chari and David (2012) and Roberts and Dowling (2002), we used a new cut-off point (i.e., FSR values greater than zero) to categorize firms with superior performance. This selection criterion yielded a greater subsample of 3,388 firm-year observations with a lower FSR value (mean=0.02, $\mathrm{SD}=0.06$ ), and we again obtained results consistent with our original findings.

Accounting for potential endogeneity. In addition to the random-effects dynamic panel models with Nickell bias corrections, we used Arrellano and Bond's (1991) two-step system-generalized method of moments (GMM) technique (employing the "xtabond2" command in the Stata software package) to reestimate all our models. Consulting prior studies (e.g., Gubbi et al., 2010; Xia \& Walker, 2015), we identified two instruments, namely, net profit margin and corporate ownership, for the lagged 
performance measure. The results obtained from GMM estimations were consistent with the findings reported in Table 3 with only minor changes in the values of coefficients, thereby suggesting our results are robust.

Lastly, we examine the possibility that firms' BG affiliation is self-selected, either due to superior prior performance or market power, making the BG variable potentially endogenous. Conceptually, this possibility is low, as sample firms are not selected into BG on a yearly basis. Rather, their BG affiliation appears to be stable over time. Nonetheless, to empirically eliminate this possibility, we conducted endogeneity correction procedures using treatment regression (Stata's "etregress" command) (Certo, Busenbark, Woo, \& Semadeni, 2016) with firm's market power and prior performance as instrumental variables, and the results are consistent with the results reported in Table 3 (Models 1 and 2). All robustness test results are available upon request.

\section{DISCUSSION}

Integrating the literature related to the differential roles of the state in directing economic activities with neo-institutional theorists' concerns about organizational responses to institutional forces (e.g., Greenwood et al., 2011; Kohli, 2004; Oliver, 1991; Witt \& Redding, 2013; Zhang \& Whitley, 2013), we focus on two different state capitalist systems to explain organizational performance heterogeneity arising from the institutional environments of two large emerging economies, namely, China (representing a state-led system) and India (representing a co-governed system). We theorize that this institutional diversity imposes different expectations on business organizations. Accordingly, we investigate the diverging effect of BGs, an organizational form that emerges with the direct and indirect encouragement of the state, on the persistence of superior firm performance in these two contrasting institutional environments. We then examine the moderating role of the affiliated firms' internationalization strategy.

Our empirical analysis of a panel of large Chinese and Indian manufacturing firms provides support for our institutional contingency hypothesis. Advancing from the baseline effect of BG affiliation on the persistence of superior firm performance, which remains a debated issue in the literature (Chari \& David, 2012; Chittoor et al., 2015; Estrin et al., 2009), our findings suggest that this BG effect 
significantly differs across contrasting institutional environments. Specifically, the influence of BG affiliation on superior performance persistence is, on average, stronger in China's state-led system than in India's co-governed system. This finding (along with robustness tests directly measuring resource allocations) suggests that different BG resource reallocation mechanisms are likely to be emphasized as a strategic response to institutional pressures. Our theorized effect of different types of state capitalism on the resource allocations of BG firms is further strengthened by the findings that as firms move away from the primacy of their home institutional context (i.e., through internationalization), the effect of BG affiliation on superior performance persistence (and associated resource allocation strategies) tends to converge between Chinese and Indian firms. Furthermore, robustness tests related to comparing just the non-state-owned firms across the two countries as well as resource allocation within the BG firms, along with the incorporation of additional aspects related to power and ownership and testing for endogeneity concerns, also provide further evidence for our theorized mechanism related to different types of state capitalism in explaining differences in the performance persistence of BG-affiliated firms.

Our study makes several contributions to related streams of research. First, we contribute to the BG literature. Much of the existing literature on BGs in developing economies has focused on the emergence of this organizational form as a structural response to external market failures, owing to the presence of institutional voids. However, there is less research on the strategic choices and associated performance implications of the underlying attributes and governance structures of BGs. Such research is particularly important, as prior studies show that the BG effect on affiliates' performance varies even within environments with similar institutional voids. For instance, Carney et al. (2011: 452) caution researchers about "drawing broad conclusions regarding institutional development" and call for an exploration of alternative mechanisms that explain the efficacy of BGs. Our study contributes to this line of thinking by identifying alternative institutional factors that influence organizational outcomes in BGs. In particular, we show that BG effects are associated with the diversity in forms of state capitalism in developing economies. The implication is that the absence of market-supporting infrastructure in certain economies does not create a vacuum of institutions (Chakrabarty \& Bass, 2014; Mair, Marti, \& 
Ventresca, 2012); instead, it allows the state to develop alternative mechanisms that influence the behavior of economic actors. Incorporating the role and context of the state in its interactions with organizational actors allows us to better understand the diverging organizational responses in developing economies where state capitalism serves as an alternative economic coordination mechanism that fills the voids of well-established formal market institutions (Doh, et al., 2017). Furthermore, we demonstrate that BGs emphasize different resource allocation mechanisms because of the diversity in home institutional environments and show that the choice of mechanism is conditioned by BG affiliates' exposure to external institutional contexts when they internationalize. By emphasizing the diversity of state capitalism across institutional contexts and elucidating their implications for BGs' strategic choices, our study complements and expands the institutional void approach to BGs.

Second, in focusing on state-business interactions in economic governance to conduct an institutional comparative analysis, our paper extends research on comparative institutionalism, both theoretically and empirically. Existing comparative institutionalism research typically uses a multidimensional view that focuses on institutional differences reflected in different domains of a country's institutional or business systems, such as regulatory, financial, education, and industrial relations (Hall \& Soskice, 2001; Jackson \& Deeg, 2008). Emphasizing the different role of the state in coordinating the economy allows us to look at alternative aspects of the underlying institutional differences in a comparative setting and hence offer new insights into institutional variations arising from the difference in type, rather than the difference in degree.

Third, our study contributes to the recent literature that has called for more research on how nonmarket institutions and logics influence organizational actions and outcomes. In their study of Spanish firms, Greenwood et al. (2010) demonstrate how the influence of the state and church (two nonmarket institutions) across the country's sub-regions in Spain influences firms' decisions regarding organizational downsizing. Our study advances the understanding of the evolution of state capitalism across two countries (China and India) with contrasting systems and shows how the political-economic context leads to different institutional expectations for organizations (Khanna \& Yafeh, 2007). We then 
show that the diversity of institutional expectations and the associated legitimacy requirements in turn influence organizational strategies, especially in the context of BGs. This diversity in forms of state capitalism and their associated logics, along with other nonmarket logics related to the primacy of family, social structure, and religion that are prevalent across countries, opens new frontiers for future research in international business (see Buckley, Doh \& Benischke, 2017).

This study also offers managerial implications for BGs in relation to internationalization strategy. At the group level, as BGs expand into other institutional environments, they will need to adjust their coordination functions. While the advantages associated with a BG structure in filling institutional voids can be extended into other emerging economies with institutional voids, BGs need to pay attention to the specific type of institutional environment into which they expand, as the type of institutional environments will determine the emphasis of their coordination efforts in terms of how resources should be reallocated among affiliated firms to attain institutional legitimacy and foster group success. As BG affiliates internationalize, their ability to maintain superior performance will change depending on the type of institutional environment in which they operated prior to internationalization. Their performance persistence may deteriorate if they have benefited from group-coordinated resource prioritization as a response to the institutional expectations of their home state before internationalization. As such, BG affiliates need to account for the change in their ability to maintain performance while making internationalization decisions.

We acknowledge several limitations of the current study, as they also provide avenues for future research. First, we used the empirical contexts of China and India to illustrate the different types of institutional environments in emerging economies. Given the distinct state capitalist systems in these countries (Khanna, 2007) but also their shared development paths and liberalization reforms during the time period of our study, we used these two countries as exemplars to develop preliminary theorization on how the two systems can influence the organizational strategies of a particular type of organizational form: the business group. Such a descriptive comparative approach, while benefiting from the possibility of theory development in its early stages, also has limitations because of the small number of comparative 
cases, as well as the difficulty of isolating the theorized mechanisms (Rueschemeyer, 2003). We acknowledge this limitation and claim that our results are suggestive of the possibility of differences in state capitalism influencing organizational strategies. Research has revealed a variety of Asian capitalist systems (Carney et al., 2009; Kohli, 2004) that may differ from the two state capitalist systems used in the current paper. Extending the theoretical and empirical scope of this two-country comparison and theorizing how different types of institutional systems influence different categories of firms as well as different aspects of organizational behavior, would enable us to better understand the full variety of institutional environments in emerging economies, which presents great opportunities for future research.

Second, this study focuses on the effect of BGs on the persistence of affiliated firms' superior financial performance. While financial profitability is a key indicator of business success in the management literature, firm performance is multidimensional (Miller, Washburn, \& Glick, 2013). Exploring the effect of BGs on other aspects of firm performance may thus add new insights to the BG literature. Future research may utilize longitudinal data with a greater time span to examine the profitability, growth, and long-term strategic implications of the interaction of the BG effect with the diversity of institutional environments.

Third, despite our focus on publicly listed companies that present more consistent and reliable data in their annual reports because of the compliance to the information disclosure requirements set by law (Xia, Ma, Lu, \& Yiu., 2014), data reliability is always a challenge, especially in emerging economies. We hope future research can overcome this limitation with more refined and robust data. Lastly, the institutional environments in emerging economies (and in all countries for that matter) are dynamic rather than static. Therefore, the diversity of state capitalism in these environments may evolve over time owing to top-down institutional reforms and bottom-up social and organizational processes. Future research could thus add a change dimension to the evolution of state capitalist systems, which may contribute to our understanding of the dynamic institutional environments in emerging economies and beyond.

In conclusion, despite the aforementioned limitations, this study offers theoretical arguments and evidence that contribute to a deeper understanding of the institutional perspective of emerging market 
[Authors' final version]

studies. In particular, we demonstrate that diversity in the types of state capitalism explains the power dynamics and the interaction between the state and the business sector, which helps unravel the variation in BGs' resource allocation strategies and subsequently the performance persistence of their affiliates. Thus, this study provides an important contribution toward achieving an understanding of the boundary conditions that institutions impose on firm performance in emerging markets.

\section{ENDNOTES}

${ }^{1}$ Zhang and Whitley (2013) do not include either China or India in their analyses. In the theory section, we use some of their core ideas about the role of the state to elucidate the specific state-business interactions relevant for the two countries.

${ }^{2}$ Similar to other comparative empirical studies (e.g., Chacar \& Vissa, 2005; Chang, Chung \& Mahmood, 2006; Singh \& Gaur, 2009), our results are descriptive and do not allow us to isolate the precise theoretical mechanisms behind the results (see Chacar \& Vissa, 2005). However, given the extensive incorporation of controls related to firm, group, state ownership, etc., and the change in BG effect across the two countries and between purely domestic and internationalized firms, we believe that our theorized mechanism is plausible and could be guiding the differences.

${ }^{3}$ According to Worldwide Governance Indicators 2010 (global ranking in percentile), both countries have comparable degrees of formal institutional development (Government effectiveness: China 57.89, India 56.46; Regulatory Quality: China 44.50, India 39.23; Rule of Law: China 45.50, India 54.50; Control of Corruption: China 32.38, India 36.19).

${ }^{4}$ The contrast between the unitary (and autocratic) political context in China and the pluralistic political context in India is consistently demonstrated by secondary indices of the political environment. For instance, based on Freedom House's 2009 survey in which political freedom is ranked on a scale ranging from 1 (high freedom of citizens to influence political institutions) to 7 (low freedom), China scored 7 on political rights and 6 on civil liberties, whereas India scored 2 and 3, respectively. In addition, based on the Political Constraint Index (POLCON) dataset (Henisz, 2000), in which constraint on state power is 
ranked on a scale ranging from 0 (low restrictions) to 1 (high restrictions), China scored 0 on both restrictions on executive behavior and restrictions on policy changes, whereas India scored 0.74 and 0.41 , respectively. These data suggest that the political system in China affords the state high power with few restrictions, whereas the political system in India is characterized by greater checks and balances. ${ }^{5}$ In this study, we are primarily focused on the resource allocation strategies at the firm level. As correctly pointed out by one of the reviewers, managers may also behave opportunistically by diverting resources for their own interests (especially in the context of China, where there may be collusion between party members and their appointed CEOs for personal gain). While we do not discount this possibility (as well as the general tunnelling issues identified in the BG literature), we believe that managers' job security and legitimacy within the organization are tied to their ability to implement state directed initiatives, i.e., their professional survival depends on the firm-level strategic decisions they make that are aligned to the overall state expectations. While opportunistic managers may try to find alternative ways to seek personal gains, incentives for personal opportunistic gains through strategic decisions will be tempered by the need to maintain their position within the organizational and state hierarchies.

${ }^{6} \mathrm{We}$ thank one reviewer for suggesting the need to restrict our sample to firms with superior financial outcomes. In this version of the paper, we followed this advice and used the approach of Chari and David (2012) by including only firms with profitability above the industry average.

${ }^{7}$ Plot figure is available upon request. In addition to the simple slope plot, we also plotted the marginal effect, which leads to the same conclusion regarding the effect sizes.

${ }^{8}$ Same as the above.

${ }^{9}$ In addition, Lincoln et al.’s (1996) study also included trading partners (trade) tie and interlocking directors (director) tie to examine BGs' sphere of influence. However, since data on these ties are not only hard to obtain with accuracy (Lincoln and colleagues only tested two years of trade and director ties) but also less relevant to the empirical context of our study, we have not included them in our supplementary analyses on resource allocation. 
[Authors' final version]

\section{REFERENCES}

Alfaro, L., \& Chari, A. 2014. Deregulation, Misallocation, and Size: Evidence from India. Journal of Law and Economics, 57:897-936.

Arrellano, M., \& Bond, E. 1991. Some tests of specification for panel data. Review of Economic Studies, 58: 277-297.

Baltagi, B. 1995. Econometric analysis of panel data. New York: Wiley.

Banalieva, E. R., Eddleston, K. A., \& Zellweger, T. M. 2015. When do family firms have an advantage in transitioning economies? Toward a dynamic institution-based view. Strategic Management Journal, 36(9): 1358-1377.

Brouthers, K. D., \& Dikova, D. 2010. Acquisitions and real options: The greenfield alternative. Journal of Management Studies, 47(6): 1048-1071.

Buckley, P.J., Clegg, L.J., Voss, H., Cross, Adam R., Liu, X. \& Zeng, P. 2018. A retrospective and agenda for future research on Chinese outward foreign direct investment. Journal of International Business Studies, 49: 4-23.

Buckley, P.J., Doh, J.P. \& Benischke, M.H. 2017. Towards a renaissance in international business research? Big questions, grand challenges, and the future of IB scholarship. Journal of International Business Studies, 48: 1045-1064.

Carney, M., Gedajlovic, E., Heugens, P., van Essen, M., \& van Oosterhout, J. 2011. Business group affiliation, performance, context, and strategy: A meta-analysis. Academy of Management Journal, 54(3): 437-460.

Carney, M., Shapiro, D., \& Tang, Y. 2009. Business group performance in China: Ownership and temporal considerations. Management and Organization Review, 5(2): 167-193.

Carney, R. W. \& Witt, M. A. 2014. The role of the state in Asian business systems. In M. A. Witt \& G. Redding (Eds), The Oxford handbook of Asian business systems: 538-560. Oxford: Oxford University Press.

Certo, S. T.; Busenbark, J. R.; Woo, H., \& Semadeni, M. 2016. Sample selection bias and Heckman models in strategic management research. Strategic Management Journal, 37: 2639-2657. 
[Authors' final version]

Cestone, G. \& Fumagalli, C., 2005. The strategic impact of resource flexibility in business groups. RAND Journal of Economics, 36(1): 193-214.

Chacar, A., Newburry, W., \& Vissa, B. 2010. Bringing institutions into performance persistence research: Exploring the impact of product, financial, and labor market institutions. Journal of International Business Studies, 41: 1119-1140.

Chacar, A., \& Vissa, B. 2005. Are emerging economies less efficient? Performance persistence and the impact of business group affiliation. Strategic Management Journal, 26(10): 933-946.

Chakrabarty, S., \& Bass A. E. 2014. Institutionalizing ethics in institutional voids: Building positive ethical strength to serve women microfinance borrowers in negative contexts. Journal of Business Ethics, 119:529-542.

Chang, S. J., Chung, C. N., \& Mahmood, I. P. 2006. When and how does business group affiliation promote firm innovation? A tale of two emerging economies. Organization Science, 17(5): 637656.

Chang, S. J., \& Hong, J. 2000. Economic performance of group-affiliated companies in Korea: Intragroup resource sharing and internal business transactions. Academy of Management Journal, 43: 429-448.

Chari, M. R. D., \& David, P. 2012. Sustaining superior performance in an emerging economy: An empirical test in the Indian context. Strategic Management Journal, 33: 217-229.

Chittoor, R., Kale, P., \& Puranam, P. 2015. Business groups in developing capital markets: Towards a complementarity perspective. Strategic Management Journal, 36(9): 1277-1296.

Choi, J., \& Wang, H. 2009. Stakeholder relations and the persistence of corporate financial performance. Strategic Management Journal, 30(8): 895-907.

Colpan, A. M., Hikino, T., \& Lincoln, J. R. 2010. The Oxford handbook of business groups. Oxford: Oxford University Press.

Cui, L., \& Jiang, F. 2012. State ownership effect on firms' FDI ownership decisions under institutional pressure: A study of Chinese outward-investing firms. Journal of International Business Studies, 43(3): 264-284. 
[Authors' final version]

Dastidar, S. G., Fisman, R., \& Khanna, T. 2008. Testing limits to policy reversal: Evidence from Indian privatizations. Journal of Financial Economics, 89: 513-526.

Dawson, J. F., \& Richter, A. W. 2006. Probing three-way interactions in moderated multiple regression: Development and application of a slope difference test. Journal of Applied Psychology, 91: 917-926.

Doh, J., Rodrigues, S., Saka-Helmhout, A. \& Makhija, M. 2017. International business responses to institutional voids. Journal of International Business Studies, 48: 293-307.

Estrin, S., Poukliakova, S., \& Shapiro, D. 2009. The performance effects of business groups in Russia. Journal of Management Studies, 46(3): 393-420.

Fan, G., Wang, X., \& Zhu, H. 2012. NERI Index of Marketization of China's Provinces. Economic Science Press (in Chinese): Beijing.

Freedom House. 2009. https://freedomhouse.org/report/freedom-world/freedom-world-2009. [accessed on May $26^{\text {th }}, 2018$ ]

Gaur, A.S., Ma, X., \& Ding, Z. 2018. Home country supportiveness/unfavorableness and outward foreign direct investment from China. Journal of International Business Studies, 49(3): 324-345.

Gedajlovic, E., \& Shapiro, D. M. 2002. Ownership structure and firm profitability in Japan. Academy of Management Journal, 45(3), 565-575.

Ghemawat, P. \& Khanna, T. 1998. The nature of diversified business groups: A research design and two case studies. The Journal of Industrial Economics, 46(1): 35-61.

Gopalan, R., Nanda, V. \& Seru, A. 2007. Affiliated firms and financial support: Evidence from Indian business groups. Journal of Financial Economics, 86(3): 759-795.

Greenwood, R., Diaz, A. M., Li, S. X., \& Lorente, J. C. 2010. The multiplicity of institutional logics and the heterogeneity of organizational responses. Organization Science, 21(2): 521-539.

Greenwood, R., Raynard, M., Kodeih, F., Micelotta, E. R., \& Lounsbury, M. (2011). Institutional complexity and organizational responses. The Academy of Management Annals, 5(1), 317-371.

Gryglewicz, S. 2011. A theory of corporate financial decisions with liquidity and solvency concerns. Journal of Financial Economics, 99(2): 365-384. 
[Authors' final version]

Gubbi, S. R., Aulakh, P. S., Ray, S., Sarkar, M. B., \& Chittoor, R. 2010. Do international acquisitions by emerging-economy firms create shareholder value? The case of Indian firms. Journal of International Business Studies, 41(3): 397-418.

Gubbi, S. R., Aulakh, P. S., \& Ray, S. 2015. International search behavior of business group affiliated firms: Scope of institutional changes and intragroup heterogeneity. Organization Science, 26(5): $1485-1501$.

Guest, P., \& Sutherland, D. 2010. The impact of business group affiliation on performance: Evidence from China's 'national champions. Cambridge Journal of Economics, 34(4): 617-631.

Gulati, R., \& Westphal, J.D. 1999. Cooperative or controlling? The effects of CEO-board relations and the content of interlocks on the formation of joint ventures. Administrative Science Quarterly, 44(3): 473-506.

Hall, P. A., \& Soskice, D. 2001. Varieties of capitalism: The institutional foundations of comparative advantage. Oxford: Oxford University Press.

Hancké, B., Rhodes, M. \& Thatcher, M. 2007. Beyond varieties of capitalism: Conflict, contradictions, and complementarities in the European economy. Oxford: Oxford University Press.

Henisz, W.J. 2000. The institutional environment for economic growth. Economics and Politics, 12(1): $1-31$.

Hu, H. W., \& Cui, L. 2014. Outward foreign direct investment of publicly listed firms from China: A corporate governance perspective. International Business Review, 23: 750-760.

Hotho, J. J. 2014. From typology to taxonomy: A configurational analysis of national business systems and their explanatory power. Organization Studies, 35(5): 671-702.

Huang, Y. 2008. Capitalism with Chinese characteristics: Entrepreneurship and the state. New York: Cambridge University Press.

Jackson, G., \& Deeg, R. 2008. Comparing capitalisms: Understanding institutional diversity and its implications for international business. Journal of International Business Studies, 39(4): 540-561.

Jeffries, I. 2006. China: A guide to economic and political developments. Routledge.

Jia, N., Shi, J., \& Wang, Y. 2013. Coinsurance within business groups: Evidence from related party transactions in an emerging market. Management Science, 59(10): 2295-2313. 
[Authors' final version]

Keister, L. 2000. Chinese business groups: The structure and impact of interfirm relations during economic development. Oxford: Oxford University Press.

Khanna, T., \& Palepu, K. 1997. Why focused strategies may be wrong for emerging markets. Harvard Business Review, 75: 41-51.

Khanna, T., \& Palepu, K. 1999. Policy shocks, market intermediaries, and corporate strategy: the evolution of business groups in Chile and India. Journal of Economic and Management Strategy, 8: $271-310$.

Khanna, T., \& Palepu, K. 2000. Is group affiliation profitable in emerging markets? An analysis of diversified Indian business groups. Journal of Finance, 55(2): 867-891.

Khanna, T., \& Palepu, K. 2010. Winning in emerging markets: A road map for strategy and execution. Boston, MA: Harvard Business Press.

Khanna, T., \& Rivkin, J. W. 2001. Estimating the performance effects of business groups in emerging markets. Strategic Management Journal, 22: 45-74.

Khanna, T., \& Yafeh, Y. 2005. Business groups and risk sharing around the world. Journal of Business, 78(1): 301-340.

Khanna, T., \& Yafeh, Y. 2007. Business groups in emerging markets: Paragons or parasites. Journal of Economic Literature, XLV: 331-372.

Khanna, T. 2007. Billions of entrepreneurs: How China and India are reshaping their futures and yours. HBS Publishing.

Kochanek, S. 1996. Liberalization and business lobbying in India. Journal of Commonwealth and Comparative Politics, 34(3): 155-173.

Kohli, A. 2004. State-directed development: Political power and industrialization in the global periphery. New York: Cambridge University Press.

Kohli. A. 2006a. Politics of economic growth in India, 1980-2005. Part I: The 1980s. Economic and Political Weekly, 41(13): 1251-1259.

Kohli. A. 2006b. Politics of economic growth in India, 1980-2005. Part II: The 1990s and beyond. Economic and Political Weekly, 41(14): 1361-1370. 
[Authors' final version]

Kohli, A. 2007. State, business, and economic growth in India. Studies in Comparative International Development, 42: 87-114.

Kumar, N., \& Chadha, A. 2009. India's outward foreign direct investments in steel industry in a Chinese comparative perspective. Industrial and Corporate Change, 18: 249-267.

Lamin, A. 2013. The business group as an information resource: An investigation of business group affiliation in the Indian software services industry. Academy of Management Journal, 56(5): 14871509.

Lee, J. 2009. State-owned enterprises in China: Reviewing the evidence. OECD Working Paper on Privatisation and Corporate Governance of State Owned Assets.

Lee, K., \& Kang, Y-S. 2010. Business groups in China. In A. Colpan, T. Hikino, \& J. Lincoln (Eds), The Oxford handbook of business groups: 210-236. New York: Oxford University Press.

Li, M. H., Cui, L., \& Lu, J. 2014. Varieties in state capitalism: Outward FDI strategies of central and local state-owned enterprises from emerging economy countries. Journal of International Business Studies, 45(8): 980-1004.

Li, M. H., Cui, L., \& Lu, J. 2017. Marketized state ownership and foreign expansion of emerging market multinationals: Leveraging institutional competitive advantages. Asia Pacific Journal of Management, 34(1): 19-46

Lien, Y.-C., Piesse, J., Strange, R., \& Filatotchev, I. 2005. The role of corporate governance in FDI decisions: Evidence from Taiwan. International Business Review, 14(6): 739-763.

Lin, L., \& Milhaupt, C. J. 2013. We are the (national) champions: Understanding the mechanisms of state capitalism in China. Stanford Law Review, 65: 697-759.

Lin, Z., Peng, M. W., Yang, H. B., \& Sun, S. L. 2009. How do networks and learning drive M\&As? An institutional comparison between China and the United States. Strategic Management Journal, 30: 1113-1132.

Lincoln, J. R., Gerlach, M. L., \& Ahmadjian, C. L. 1996. Keiretsu networks and corporate performance in Japan. American Sociological Review, 61: 67-88.

Luo, Y., \& Tung, R. L. 2007. International expansion of emerging market enterprises: A springboard perspective. Journal of International Business Studies, 38: 481-498. 
[Authors' final version]

Mair, J., Marti, I., \& Ventresca, M. J. 2012. Building inclusive markets in rural Bangladesh: How intermediaries work institutional voids. Academy of Management Journal, 55(4): 819-850.

Majumdar, S.K., \& Sen, K. 2007. The debt wish: Rent seeking by business groups and the structure of corporate borrowing in India. Public Choice, 130: 209-223.

Manikandan, K. S., \& Ramachandran, J. 2015. Beyond institutional voids: Business groups, incomplete markets, and organizational form. Strategic Management Journal, 36(4): 598-617.

Marano, V., Tashman, P. \& Kostova, T. 2017. Escaping the iron cage: Liabilities of origin and CSR reporting of emerging market multinational enterprises. Journal of International Business Studies, 48: 386-408.

Miller, C. C., Washburn, N. T., \& Glick, W. H. 2013. The myth of firm performance. Organization Science, 24(3): 948-964.

Mishra, R.K. 2009. State owned enterprises in India: Reviewing the evidence. OECD Working Paper on Privatisation and Corporate Governance of State Owned Assets.

Musacchio, A., \& Lazzarini, S.G. 2012. Leviathan in business: Varieties of state capitalism and their implications for economic performance. Harvard Business School Working Paper, No. 12-108, June.

Musacchio, A., Lazzarini, S.G., \& Aguilera, R. 2015. New varieties of state capitalism: Strategic and governance implications. Academy of Management Perspectives, 29(1): 115-131.

Nee, V., \& Opper, S. 2007. On politicized capitalism. In V. Nee \& R. Swedberg (Eds), On capitalism: 93-127. Palo Alto, CA: Stanford University Press.

Nee, V. 1992. Organizational dynamics of market transition: Hybrid forms, property rights, and mixed economy in China. Administrative Science Quarterly, 37(1): 1-27.

Nickell, S. 1981. Biases in dynamic models with fixed effects. Econometrica, 49(6): 1417-1426.

Oliver, C. 1991. Strategic responses to institutional processes. Academy of Management Review, 16(1): 145-179.

Peng, M. W. 2003. Institutional transitions and strategic choices. Academy of Management Review, 28(2): 275-296. 
[Authors' final version]

Phillips, P. C. B., \& Sul, D. 2007. Bias in dynamic panel estimation with fixed effects, incidental trends and cross section dependence. Journal of Econometrics, 137: 162-188.

Ramamurti, R., \& Hilemann, J. 2018. What is "Chinese" about Chinese multinationals? Journal of International Business Studies, 49: 34-48.

Roberts, P. W., \& Dowling, G. R. 2002. Corporate reputation and sustained superior financial performance. Strategic Management Journal, 23(12): 1077-1093.

Rodrick, D., \& A. Subramanian. 2005. From "Hindi Growth" to productivity surge: The mystery of the Indian growth transition. IMF Staff Papers, 52(2): 193-228.

Rueschemeyer, D. 2003. Can one or a few cases yield theoretical gains? In J. Mahoney \& D.

Ruesschemeyer (Eds), Comparative historical analysis in the social sciences: 305-336. New York: Cambridge University Press.

Sarkar, J. 2010. Business groups in India. In A. Colpan, T. Hikino, \& J. Lincoln (Eds), The Oxford handbook of business groups: 294-321. New York: Oxford University Press.

Siegel, J. \& Choudhury, P. 2012. A reexamination of tunneling and business groups: New data and new methods. Review of Financial Studies, 25(6): 1763-1798.

Singh, D.A., \& Gaur, A.S. 2009. Business group affiliation, firm governance, and firm performance: Evidence from China and India. Corporate Governance: An International Review, 17(4): 411-425.

Suchman, M. C. 1995. Managing legitimacy: Strategic and institutional approaches. Academy of Management Review, 20(3): 571-610.

Sullivan, D. 1994. Measuring the degree of internationalization of a firm. Journal of International Business Studies, 25(2): 325-342.

Tallman, S., \& Li, J. T. 1996. Effects of international diversity and product diversity on the performance of multinational firms. Academy of Management Journal, 39(1): 179-196.

The Economist. 2012. The visible hand. Special Report: State Capitalism. January 21: 1-18.

The Economist. 2016a. Tata Group: Mistry's Elephant. September $24^{\text {th }}$.

The Economist. 2016b. Tata Group: Clash of the Tatas. November $19^{\text {th }}$.

Whitley, R. 1999. Divergent capitalisms: The social structuring and change in business systems.

Oxford: Oxford University Press. 
[Authors' final version]

Whitley, R. 2003. How national are business systems? The role of different state types and complementary institutions in constructing homogenous systems of economic co-ordination and control. Manchester Business School.

Witt, M. A., \& Redding, G. 2013. Asian business systems: Institutional comparison, clusters and implications for varieties of capitalism and business systems theory. Socio-Economic Review, 11(2): 265-300.

Witt, M.A., de Castro, L.R.K., Amaeshi, K., Mahroum, S., Bohle, D. \& Saez, L. 2018. Mapping the business systems of 61 major economies: A taxonomy and implications for varieties of capitalism and business systems research. Socio-Economic Review, 16(1): 5-38.

Xia, F., \& Walker, G. 2015. How much does owner type matter for firm performance? Manufacturing firms in China 1998-2007. Strategic Management Journal, 36: 576-585.

Xia, J., Ma, X., Lu, J. W., \& Yiu, D. W. 2014. Outward foreign direct investment by emerging market firms: A resource dependence logic. Strategic Management Journal, 35(9): 1343-1363.

Zhang, X. \& Whitley, R., 2013. Changing macro-structural varieties of East Asian capitalism. SocioEconomic Review, 11(2): 301-336. 
Table 1 Sample description

\begin{tabular}{|c|c|c|}
\hline & $\begin{array}{l}\text { Chinese } \\
\text { Subsample }\end{array}$ & $\begin{array}{l}\text { Indian } \\
\text { Subsample }\end{array}$ \\
\hline Number of firms & 641 & 512 \\
\hline Number of group-affiliated firms & 281 & 311 \\
\hline Percentage of group-affiliated firms & $43.84 \%$ & $60.74 \%$ \\
\hline Number of internationalized firms ${ }^{a}$ & 468 & 327 \\
\hline Percentage of internationalized firms & $73.01 \%$ & $63.87 \%$ \\
\hline Market capitalization, sample firm average, 2005-2010 (mil. USD) & 728.42 & 513.45 \\
\hline Market capitalization, sample firm total, 2005-2010 (bn. USD) ${ }^{b}$ & 2801.5 & 1577.32 \\
\hline GDP, 2005-2010 (bn. USD) $)^{c}$ & 23903.61 & 7348.17 \\
\hline Sample firm market cap. / GDP & $11.72 \%$ & $21.47 \%$ \\
\hline \multicolumn{3}{|l|}{ NAICS 3-digit industries (usable firm-year observations): } \\
\hline . $\quad$ Food Manufacturing & 83 & 82 \\
\hline Beverage \& Tobacco Product Manufacturing & 94 & 35 \\
\hline Textile Mills & 49 & 69 \\
\hline Textile Product Mills & 79 & 82 \\
\hline Apparel Manufacturing & 49 & 11 \\
\hline Leather \& Allied Product Manufacturing & 0 & 4 \\
\hline Wood Product Manufacturing & 4 & 8 \\
\hline . $\quad$ Paper Manufacturing & 74 & 35 \\
\hline Printing \& Related Support Activities & 8 & 0 \\
\hline - Petroleum \& Coal Products Manufacturing & 23 & 27 \\
\hline Chemical Manufacturing & 621 & 445 \\
\hline Plastics \& Rubber Products Manufacturing & 56 & 54 \\
\hline Nonmetallic Mineral Product Manufacturing & 128 & 131 \\
\hline Primary Metal Manufacturing & 139 & 171 \\
\hline Fabricated Metal Product Manufacturing & 63 & 82 \\
\hline Machinery Manufacturing & 286 & 144 \\
\hline Computer \& Electronic Product Manufacturing & 192 & 47 \\
\hline . $\quad$ Electrical Equipment, Appliance, \& Component Manufacturing & 149 & 84 \\
\hline . $\quad$ Transportation Equipment Manufacturing & 198 & 108 \\
\hline - $\quad$ Furniture \& Related Product Manufacturing & 8 & 0 \\
\hline Miscellaneous Manufacturing & 11 & 12 \\
\hline Total & 2314 & 1631 \\
\hline
\end{tabular}

Notes:

${ }^{a}$ Firms with foreign sales or foreign subsidiaries recorded in at least one year during the 2005-2010 period.

${ }^{b}$ Because of missing data for certain firm-year observations, we use estimated values based on the average market capitalization in each country-year.

${ }^{c}$ Data from the World Bank (www.data.worldbank.org, accessed April 10, 2015). 
Table 2 Descriptive statistics and correlations

\begin{tabular}{|c|c|c|c|c|c|c|c|c|c|c|c|c|c|c|c|c|c|c|}
\hline & Variables & Mean & S.D. & 1 & 2 & 3 & 4 & 5 & 6 & 7 & 8 & 9 & 10 & 11 & 12 & 13 & 14 & 15 \\
\hline \multicolumn{19}{|c|}{ Panel A Full sample $(N=1875)$} \\
\hline 1 & FSR & 0.06 & 0.06 & 1.00 & & & & & & & & & & & & & & \\
\hline 2 & $\mathrm{FSR}_{\mathrm{t}-1}$ & 0.07 & 0.06 & $0.50 *$ & 1.00 & & & & & & & & & & & & & \\
\hline 3 & Firm size & 12.78 & 0.99 & -0.03 & $0.08 *$ & 1.00 & & & & & & & & & & & & \\
\hline 4 & Firm age & 22.90 & 19.79 & -0.04 & $-0.05^{*}$ & $-0.11 *$ & 1.00 & & & & & & & & & & & \\
\hline 5 & IPO age & 9.34 & 5.22 & -0.01 & -0.01 & $0.05^{*}$ & $0.17 *$ & 1.00 & & & & & & & & & & \\
\hline 6 & Sales growth & 9.30 & 40.00 & 0.00 & $-0.12 *$ & $0.24 *$ & 0.00 & -0.03 & 1.00 & & & & & & & & & \\
\hline 7 & Leverage & 0.23 & 0.18 & $0.51 *$ & $0.29 *$ & $0.04 *$ & 0.03 & 0.02 & -0.02 & 1.00 & & & & & & & & \\
\hline 8 & State & 0.44 & 0.50 & $0.04 *$ & $0.07 *$ & $0.10^{*}$ & $-0.41 *$ & $0.07 *$ & -0.03 & -0.02 & 1.00 & & & & & & & \\
\hline 9 & IND ownership & 13.83 & 21.80 & $-0.05^{*}$ & -0.03 & $-0.15^{*}$ & $0.36^{*}$ & $-0.10^{*}$ & 0.03 & $0.06^{*}$ & $-0.53 *$ & 1.00 & & & & & & \\
\hline 10 & SFI ownership & 9.69 & 11.34 & 0.02 & 0.01 & $-0.08^{*}$ & $0.38 *$ & $0.05^{*}$ & -0.02 & 0.04 & $-0.29 *$ & $0.17 *$ & 1.00 & & & & & \\
\hline 11 & FOR ownership & 4.50 & 13.97 & 0.01 & -0.01 & -0.03 & $0.22 *$ & 0.01 & 0.04 & 0.00 & $-0.18 *$ & 0.00 & $0.05^{*}$ & 1.00 & & & & \\
\hline 12 & Market power & 0.19 & 0.29 & -0.04 & -0.04 & $0.32 *$ & $0.10^{*}$ & -0.03 & $0.08^{*}$ & 0.00 & $-0.12 *$ & $0.13 *$ & $0.08^{*}$ & 0.04 & 1.00 & & & \\
\hline 13 & BG size & 1.67 & 4.61 & -0.02 & -0.01 & 0.02 & 0.04 & 0.04 & -0.01 & -0.03 & $0.10^{*}$ & $-0.09 *$ & $0.11^{*}$ & -0.04 & 0.01 & 1.00 & & \\
\hline 14 & BG diversification & 3.20 & 5.16 & 0.03 & 0.00 & $-0.05^{*}$ & $0.31 *$ & $0.08 *$ & -0.03 & 0.04 & $-0.16^{*}$ & $0.05 *$ & $0.28^{*}$ & $-0.09 *$ & $0.05^{*}$ & $0.55^{*}$ & 1.00 & \\
\hline 15 & $\mathrm{BG}$ & 0.51 & 0.50 & 0.04 & 0.02 & 0.01 & $0.10^{*}$ & 0.04 & -0.01 & 0.03 & 0.04 & -0.01 & $0.16^{*}$ & $-0.15^{*}$ & 0.01 & $0.36^{*}$ & $0.62 *$ & 1.00 \\
\hline 16 & INT & 0.32 & 1.96 & 0.02 & 0.01 & -0.02 & $0.08^{*}$ & 0.02 & 0.00 & 0.00 & -0.04 & 0.00 & $0.18^{*}$ & 0.01 & -0.02 & $0.08^{*}$ & $0.16^{*}$ & $0.05 *$ \\
\hline \multicolumn{19}{|c|}{ Panel B Chinese sample $(N=1125)$} \\
\hline 1 & FSR & 0.06 & 0.06 & 1.00 & & & & & & & & & & & & & & \\
\hline 2 & $\mathrm{FSR}_{\mathrm{t}-1}$ & 0.07 & 0.06 & $0.52 *$ & 1.00 & & & & & & & & & & & & & \\
\hline 3 & Firm size & 12.97 & 0.98 & 0.01 & $0.08^{*}$ & 1.00 & & & & & & & & & & & & \\
\hline 4 & Firm age & 12.34 & 5.01 & -0.03 & 0.00 & 0.01 & 1.00 & & & & & & & & & & & \\
\hline 5 & IPO age & 9.62 & 3.22 & -0.04 & -0.01 & -0.01 & $0.40^{*}$ & 1.00 & & & & & & & & & & \\
\hline 6 & Sales growth & 8.47 & 36.62 & -0.01 & $-0.14 *$ & $0.18^{*}$ & 0.00 & -0.06 & 1.00 & & & & & & & & & \\
\hline 7 & Leverage & 0.22 & 0.19 & $0.44 *$ & $0.28^{*}$ & $0.10^{*}$ & -0.01 & 0.00 & -0.02 & 1.00 & & & & & & & & \\
\hline 8 & State & 0.70 & 0.46 & 0.01 & 0.06 & -0.05 & $-0.08 *$ & $0.10^{*}$ & -0.01 & 0.00 & 1.00 & & & & & & & \\
\hline 9 & IND ownership & 0.93 & 5.31 & 0.04 & 0.04 & -0.01 & $0.17 *$ & $-0.14 *$ & -0.03 & 0.01 & $-0.23 *$ & 1.00 & & & & & & \\
\hline
\end{tabular}


Table 2

(Continued)

\begin{tabular}{|c|c|c|c|c|c|c|c|c|c|c|c|c|c|c|c|c|c|c|}
\hline 10 & SFI ownership & 5.29 & 7.59 & 0.04 & $0.06^{*}$ & 0.02 & -0.01 & 0.03 & -0.02 & 0.05 & 0.04 & -0.02 & 1.00 & & & & & \\
\hline 11 & FOR ownership & 1.83 & 6.95 & 0.02 & -0.02 & 0.03 & -0.01 & -0.01 & 0.02 & 0.02 & -0.04 & -0.04 & -0.03 & 1.00 & & & & \\
\hline 12 & Market power & 0.14 & 0.25 & -0.05 & -0.03 & $0.35^{*}$ & 0.00 & -0.01 & $0.12^{*}$ & 0.01 & 0.00 & -0.02 & -0.05 & 0.01 & 1.00 & & & \\
\hline 13 & BG size & 1.87 & 4.59 & -0.05 & -0.02 & 0.01 & -0.03 & $0.08^{*}$ & 0.01 & -0.05 & $0.16^{*}$ & $-0.06 *$ & $0.09 *$ & -0.02 & 0.05 & 1.00 & & \\
\hline 14 & BG diversification & 2.08 & 3.04 & 0.06 & 0.05 & -0.02 & $-0.07 *$ & 0.06 & -0.01 & 0.02 & $0.16^{*}$ & $-0.10 *$ & $0.10^{*}$ & -0.01 & $0.06^{*}$ & $0.46^{*}$ & 1.00 & \\
\hline 15 & $\mathrm{BG}$ & 0.48 & 0.50 & 0.04 & 0.04 & 0.02 & $-0.14^{*}$ & -0.02 & 0.03 & 0.02 & $0.26^{*}$ & $-0.13^{*}$ & $0.12^{*}$ & -0.01 & 0.02 & $0.44^{*}$ & $0.73 *$ & 1.00 \\
\hline 16 & INT & 0.25 & 1.12 & 0.02 & 0.00 & 0.00 & $0.08^{*}$ & $0.11 *$ & -0.01 & 0.01 & 0.00 & 0.00 & $0.13^{*}$ & $0.15^{*}$ & 0.00 & 0.03 & 0.02 & 0.00 \\
\hline \multicolumn{19}{|c|}{ Panel C Indian sample $(N=750)$} \\
\hline 1 & FSR & 0.05 & 0.06 & 1.00 & & & & & & & & & & & & & & \\
\hline 2 & $\mathrm{FSR}_{\mathrm{t}-1}$ & 0.06 & 0.06 & $0.47 *$ & 1.00 & & & & & & & & & & & & & \\
\hline 3 & Firm size & 12.52 & 0.95 & $-0.10^{*}$ & 0.05 & 1.00 & & & & & & & & & & & & \\
\hline 4 & Firm age & 37.05 & 23.10 & -0.02 & -0.03 & 0.06 & 1.00 & & & & & & & & & & & \\
\hline 5 & IPO age & 8.90 & 7.26 & 0.01 & -0.02 & $0.08^{*}$ & $0.28^{*}$ & 1.00 & & & & & & & & & & \\
\hline 6 & Sales growth & 10.47 & 44.40 & 0.02 & $-0.09 *$ & $0.34 *$ & -0.02 & -0.01 & 1.00 & & & & & & & & & \\
\hline 7 & Leverage & 0.23 & 0.15 & $0.65^{*}$ & $0.32 *$ & -0.03 & 0.01 & 0.04 & -0.02 & 1.00 & & & & & & & & \\
\hline 8 & State & 0.06 & 0.24 & 0.03 & 0.00 & -0.02 & 0.05 & 0.04 & -0.04 & 0.01 & 1.00 & & & & & & & \\
\hline 9 & IND ownership & 32.42 & 23.11 & -0.04 & 0.01 & 0.01 & $-0.21^{*}$ & $-0.09 *$ & 0.04 & $0.08^{*}$ & $-0.24^{*}$ & 1.00 & & & & & & \\
\hline 10 & SFI ownership & 16.02 & 12.76 & 0.05 & 0.02 & 0.04 & $0.15^{*}$ & $0.11 *$ & -0.04 & -0.01 & -0.03 & $-0.32 *$ & 1.00 & & & & & \\
\hline 11 & FOR ownership & 8.34 & 19.54 & 0.03 & 0.01 & 0.01 & $0.11^{*}$ & 0.03 & 0.04 & -0.01 & -0.07 & $-0.26^{*}$ & $-0.08^{*}$ & 1.00 & & & & \\
\hline 12 & Market power & 0.26 & 0.33 & -0.01 & -0.02 & $0.44^{*}$ & -0.04 & -0.03 & $0.10^{*}$ & -0.02 & 0.00 & -0.01 & 0.02 & -0.01 & 1.00 & & & \\
\hline 13 & BG size & 1.41 & 4.63 & 0.01 & 0.01 & 0.01 & $0.15^{*}$ & 0.02 & -0.04 & 0.01 & $-0.07 *$ & $-0.12 *$ & $0.20^{*}$ & $-0.08 *$ & -0.07 & 1.00 & & \\
\hline 14 & BG diversification & 4.70 & 6.78 & 0.03 & -0.01 & 0.02 & $0.24 *$ & $0.12 *$ & -0.05 & 0.04 & $-0.15^{*}$ & $-0.22 *$ & $0.22 *$ & $-0.19 *$ & -0.04 & $0.73^{*}$ & 1.00 & \\
\hline 15 & $\mathrm{BG}$ & 0.55 & 0.50 & 0.05 & 0.01 & 0.04 & $0.16^{*}$ & $0.10^{*}$ & -0.05 & 0.03 & $-0.24 *$ & $-0.13^{*}$ & $0.16^{*}$ & $-0.29 *$ & -0.03 & $0.28 *$ & $0.64 *$ & 1.00 \\
\hline 16 & INT & 0.42 & 2.70 & 0.02 & 0.03 & -0.01 & $0.07 *$ & 0.00 & -0.01 & -0.01 & -0.02 & -0.06 & $0.19 *$ & -0.04 & -0.04 & $0.33 *$ & $0.19 *$ & $0.08 *$ \\
\hline
\end{tabular}

Notes: ${ }^{*} p<0.05$. Correlations reported are for the main effects and not for the interaction terms. 
[Authors' final version]

Table 3 Hypothesis test using random-effect dynamic panel models

\begin{tabular}{|c|c|c|c|c|c|c|}
\hline & \multicolumn{2}{|c|}{ Full Sample } & \multirow{2}{*}{$\begin{array}{l}\text { Domestic } \\
\text { Model3 }\end{array}$} & \multirow{2}{*}{$\frac{\text { International }}{\text { Model4 }}$} & \multirow{2}{*}{$\frac{\text { China }}{\text { Model5 }}$} & \multirow{2}{*}{$\begin{array}{l}\text { India } \\
\text { Model6 }\end{array}$} \\
\hline & Model1 & Model2 & & & & \\
\hline \multirow[t]{2}{*}{ Intercept } & $8.06^{* * *}$ & $6.83^{* * *}$ & $5.91^{* *}$ & $12.45^{* *}$ & $6.56^{* *}$ & $13.27^{* * *}$ \\
\hline & $(1.86)$ & $(1.85)$ & (1.97) & $(4.07)$ & $(2.10)$ & $(2.65)$ \\
\hline \multirow[t]{2}{*}{ Firm size } & $-0.41^{* * *}$ & $-0.46^{* * *}$ & $-0.42^{* *}$ & $-0.97^{* * *}$ & -0.20 & $-0.98^{* * *}$ \\
\hline & $(0.14)$ & $(0.14)$ & $(0.15)$ & $(0.32)$ & $(0.16)$ & $(0.21)$ \\
\hline \multirow[t]{2}{*}{ Firm age } & $-0.02^{\dagger}$ & -0.02 & 0.00 & 0.00 & -0.02 & 0.00 \\
\hline & $(0.01)$ & $(0.01)$ & $(0.01)$ & $(0.02)$ & $(0.03)$ & $(0.01)$ \\
\hline \multirow[t]{2}{*}{ IPO age } & 0.01 & 0.01 & 0.01 & -0.01 & -0.05 & 0.02 \\
\hline & $(0.03)$ & $(0.03)$ & $(0.03)$ & $(0.07)$ & $(0.05)$ & $(0.02)$ \\
\hline \multirow[t]{2}{*}{ Sales growth } & $0.0003^{* * * *}$ & $0.0003^{* * * *}$ & $0.0003^{* * * *}$ & $0.01^{* * * *}$ & 0.00 & 0.00 \\
\hline & $(0.0001)$ & $(0.0001)$ & $(0.0001)$ & $(0.002)$ & $(0.00)$ & $(0.00)$ \\
\hline \multirow[t]{2}{*}{ Leverage } & $0.16^{* * * *}$ & $0.17^{* * * *}$ & $0.16^{* * * *}$ & -0.03 & -0.06 & $0.06^{\dagger}$ \\
\hline & $(0.03)$ & $(0.03)$ & $(0.03)$ & $(0.18)$ & $(0.04)$ & $(0.03)$ \\
\hline \multirow[t]{2}{*}{ State } & -0.21 & -0.16 & 0.10 & -0.12 & -0.24 & 0.44 \\
\hline & $(0.35)$ & $(0.37)$ & $(0.40)$ & $(0.87)$ & $(0.37)$ & $(0.96)$ \\
\hline \multirow{2}{*}{ State $\times F_{S R} R_{t-1}$} & $0.57^{*}$ & 0.07 & $-0.78^{*}$ & $3.17^{* *}$ & 0.06 & $2.37^{\dagger}$ \\
\hline & $(0.28)$ & $(0.35)$ & $(0.37)$ & $(1.03)$ & $(0.35)$ & (1.29) \\
\hline \multirow[t]{2}{*}{ IND ownership } & -0.01 & 0.01 & 0.01 & -0.01 & 0.02 & 0.00 \\
\hline & $(0.01)$ & $(0.01)$ & $(0.01)$ & $(0.02)$ & $(0.03)$ & $(0.01)$ \\
\hline \multirow[t]{2}{*}{ SFI ownership } & 0.01 & 0.02 & 0.01 & 0.03 & 0.01 & 0.02 \\
\hline & $(0.01)$ & $(0.01)$ & $(0.01)$ & $(0.03)$ & $(0.02)$ & $(0.02)$ \\
\hline \multirow[t]{2}{*}{ FOR ownership } & 0.01 & $0.02^{\dagger}$ & 0.01 & $0.05^{\dagger}$ & 0.02 & 0.02 \\
\hline & $(0.01)$ & $(0.01)$ & $(0.01)$ & $(0.03)$ & $(0.02)$ & $(0.01)$ \\
\hline \multirow[t]{2}{*}{ Market power } & -0.34 & -0.08 & -0.18 & 0.79 & -0.39 & 0.83 \\
\hline & $(0.48)$ & $(0.48)$ & $(0.51)$ & $(1.12)$ & $(0.62)$ & $(0.59)$ \\
\hline \multirow[t]{2}{*}{ BG size } & $-0.06^{\dagger}$ & -0.01 & -0.01 & -0.01 & -0.01 & 0.00 \\
\hline & $(0.03)$ & $(0.01)$ & $(0.01)$ & $(0.02)$ & $(0.01)$ & $(0.06)$ \\
\hline BG diversification & 0.05 & 0.02 & 0.01 & 0.06 & 0.06 & 0.02 \\
\hline & $(0.04)$ & $(0.04)$ & $(0.04)$ & $(0.07)$ & $(0.07)$ & $(0.05)$ \\
\hline $\mathrm{FSR}_{\mathrm{t}-1}$ & $0.44^{* * *}$ & $0.47^{* * *}$ & $0.53^{* * *}$ & $0.55^{* * * *}$ & $0.37^{* * * *}$ & $0.38^{* * * *}$ \\
\hline & $(0.03)$ & $(0.04)$ & $(0.04)$ & $(0.10)$ & $(0.04)$ & $(0.06)$ \\
\hline BG & -0.31 & 0.98 & $1.67^{*}$ & 1.79 & $-0.98^{\dagger}$ & 0.86 \\
\hline & $(0.43)$ & $(0.67)$ & $(0.71)$ & $(1.60)$ & $(0.56)$ & $(0.66)$ \\
\hline $\mathrm{BG} \times \mathrm{FSR}_{\mathrm{t}-1}$ & $0.10^{*}$ & -0.03 & $-0.16^{*}$ & -0.11 & $0.14^{* *}$ & 0.00 \\
\hline & $(0.04)$ & $(0.07)$ & $(0.07)$ & $(0.17)$ & $(0.05)$ & $(0.07)$ \\
\hline China & & $1.77^{* *}$ & $1.95^{* *}$ & 0.50 & & \\
\hline & & $(0.68)$ & $(0.72)$ & $(1.55)$ & & \\
\hline China $\times$ BG & & $-1.43^{*}$ & $-2.01^{* *}$ & -0.47 & & \\
\hline & & $(0.64)$ & $(0.68)$ & $(1.46)$ & & \\
\hline China FSR $_{\mathrm{t}-1}$ & & -0.01 & -0.07 & -0.22 & & \\
\hline & & $(0.08)$ & $(0.08)$ & $(0.19)$ & & \\
\hline China $\times$ BG $\times \mathrm{FSR}_{\mathrm{t}-1}$ & & $2.04^{* *}$ & $3.34^{* * *}$ & -0.53 & & \\
\hline & & $(0.65)$ & $(0.70)$ & $(1.54)$ & & \\
\hline INT & & & & & $-0.86^{*}$ & -0.28 \\
\hline & & & & & $(0.40)$ & $(0.38)$ \\
\hline $\mathrm{INT} \times \mathrm{BG}$ & & & & & $1.09^{*}$ & -0.32 \\
\hline & & & & & $(0.43)$ & $(0.32)$ \\
\hline $\mathrm{INT} \times \mathrm{FSR}_{\mathrm{t}-1}$ & & & & & $0.12^{\dagger}$ & 0.05 \\
\hline & & & & & $(0.07)$ & $(0.04)$ \\
\hline $\mathrm{INT} \times \mathrm{BG} \times \mathrm{FSR}_{\mathrm{t}-1}$ & & & & & $-0.16^{\dagger}$ & $0.09^{*}$ \\
\hline & & & & & $(0.09)$ & $(0.04)$ \\
\hline Year dummies & Yes & Yes & Yes & Yes & Yes & Yes \\
\hline Wald $\chi^{2}$ & $768.65^{* * * *}$ & $792.10^{* * * *}$ & $663.99^{* * * *}$ & $165.17^{* * *}$ & $438.61^{* * * *}$ & $219.58^{* * * *}$ \\
\hline$N$ & 1814 & 1814 & 1601 & 213 & 1125 & 689 \\
\hline
\end{tabular}

Notes: Standard errors in parentheses. $\dagger, *, * *$, and $* * *$ denote statistical significance at $10 \%, 5 \%, 1 \%$, and $0.1 \%$ 
[Authors' final version]

levels, respectively (two-tailed tests). 
[Authors' final version]

Table 4 Robustness tests using a subsample of privately owned listed firms

\begin{tabular}{|c|c|c|c|c|c|c|}
\hline & \multicolumn{2}{|c|}{ Full Sample } & \multirow{2}{*}{$\frac{\text { Domestic }}{\text { Model3 }}$} & \multirow{2}{*}{$\frac{\text { International }}{\text { Model } 4}$} & \multirow{2}{*}{$\frac{\text { China }}{\text { Model5 }}$} & \multirow{2}{*}{$\begin{array}{r}\text { India } \\
\text { Model6 }\end{array}$} \\
\hline & Model1 & Model2 & & & & \\
\hline \multirow[t]{2}{*}{ Intercept } & $10.37^{* * *}$ & $9.55^{* * *}$ & $7.63^{* *}$ & 6.52 & 2.38 & $13.95^{* * * *}$ \\
\hline & $(2.37)$ & $(2.35)$ & $(2.55)$ & $(4.90)$ & $(3.23)$ & $(2.75)$ \\
\hline \multirow[t]{2}{*}{ Firm size } & $-0.57^{* * * *}$ & $-0.68^{* * * *}$ & $-0.53^{* *}$ & $-0.97^{*}$ & -0.19 & $-1.04^{* * * *}$ \\
\hline & $(0.18)$ & $(0.18)$ & $(0.20)$ & $(0.39)$ & $(0.24)$ & $(0.22)$ \\
\hline \multirow[t]{2}{*}{ Firm age } & $-0.02^{\dagger}$ & -0.01 & 0.00 & -0.01 & 0.03 & 0.00 \\
\hline & $(0.01)$ & $(0.01)$ & $(0.01)$ & $(0.02)$ & $(0.05)$ & $(0.01)$ \\
\hline \multirow[t]{2}{*}{ IPO age } & 0.03 & 0.02 & 0.02 & 0.04 & -0.05 & 0.02 \\
\hline & $(0.03)$ & $(0.03)$ & $(0.03)$ & $(0.07)$ & $(0.08)$ & $(0.03)$ \\
\hline \multirow[t]{2}{*}{ Sales growth } & $0.0002^{* * *}$ & $0.0003^{* * * *}$ & $0.0002^{* * *}$ & 0.00 & 0.00 & $0.0003^{* * *}$ \\
\hline & $(0.0001)$ & $(0.0001)$ & $(0.0001)$ & $(0.00)$ & $(0.00)$ & $(0.0001)$ \\
\hline \multirow[t]{2}{*}{ Leverage } & $0.28^{* * *}$ & $0.30^{* * *}$ & $0.30^{* * *}$ & $23.41^{\text {**** }}$ & $18.69^{* * * *}$ & $0.05^{\dagger}$ \\
\hline & $(0.03)$ & $(0.03)$ & $(0.03)$ & $(2.42)$ & $(1.88)$ & $(0.03)$ \\
\hline \multirow[t]{2}{*}{ IND ownership } & -0.01 & 0.01 & 0.02 & 0.02 & 0.03 & 0.01 \\
\hline & $(0.01)$ & $(0.01)$ & $(0.01)$ & $(0.02)$ & $(0.03)$ & $(0.01)$ \\
\hline \multirow[t]{2}{*}{ SFI ownership } & -0.01 & 0.02 & 0.01 & $0.08^{*}$ & 0.03 & 0.02 \\
\hline & $(0.01)$ & $(0.02)$ & $(0.02)$ & $(0.04)$ & $(0.03)$ & $(0.02)$ \\
\hline \multirow[t]{2}{*}{ FOR ownership } & 0.01 & $0.02^{*}$ & $0.02^{\dagger}$ & $0.07^{*}$ & 0.02 & $0.02^{*}$ \\
\hline & $(0.01)$ & $(0.01)$ & $(0.01)$ & $(0.03)$ & $(0.03)$ & $(0.01)$ \\
\hline \multirow[t]{2}{*}{ Market power } & 0.11 & 0.44 & 0.33 & -0.98 & -0.08 & 0.92 \\
\hline & $(0.56)$ & $(0.56)$ & $(0.61)$ & $(1.29)$ & $(0.97)$ & $(0.61)$ \\
\hline \multirow[t]{2}{*}{ BG size } & 0.00 & -0.02 & -0.06 & 0.04 & $0.33^{*}$ & -0.01 \\
\hline & $(0.05)$ & $(0.06)$ & $(0.07)$ & $(0.08)$ & $(0.15)$ & $(0.06)$ \\
\hline \multirow[t]{2}{*}{ BG diversification } & 0.01 & 0.04 & 0.05 & -0.10 & -0.08 & 0.03 \\
\hline & $(0.05)$ & $(0.05)$ & $(0.06)$ & $(0.08)$ & $(0.15)$ & $(0.05)$ \\
\hline \multirow[t]{2}{*}{$\mathrm{FSR}_{\mathrm{t}-1}$} & $0.35^{* * * *}$ & $0.36^{* * * *}$ & $0.34^{* * * *}$ & $0.24^{*}$ & $0.19^{* * *}$ & $0.38^{* * * *}$ \\
\hline & $(0.04)$ & $(0.04)$ & $(0.04)$ & $(0.10)$ & $(0.05)$ & $(0.06)$ \\
\hline \multirow[t]{2}{*}{ BG } & -0.12 & 0.75 & 0.27 & $4.18^{* *}$ & -1.29 & 0.94 \\
\hline & $(0.56)$ & $(0.70)$ & $(0.76)$ & $(1.57)$ & $(1.17)$ & $(0.67)$ \\
\hline \multirow[t]{2}{*}{$\mathrm{BG} \times \mathrm{FSR}_{\mathrm{t}-1}$} & $0.15^{* *}$ & 0.03 & 0.08 & -0.27 & $0.21^{*}$ & -0.003 \\
\hline & $(0.05)$ & $(0.08)$ & $(0.08)$ & $(0.18)$ & $(0.10)$ & $(0.07)$ \\
\hline China & & $2.27^{* * *}$ & $2.42^{* * *}$ & $3.08^{\dagger}$ & & \\
\hline & & $(0.75)$ & $(0.81)$ & $(1.66)$ & & \\
\hline China $\times$ BG & & -1.02 & -1.56 & -2.39 & & \\
\hline & & $(0.86)$ & $(0.96)$ & $(1.79)$ & & \\
\hline China $\mathrm{FSR}_{\mathrm{t}-1}$ & & -0.06 & -0.01 & $-0.47^{*}$ & & \\
\hline & & $(0.08)$ & $(0.08)$ & $(0.20)$ & & \\
\hline China $\times$ BG $\times F S R_{t-1}$ & & $3.13^{* * * *}$ & $3.84^{* * * *}$ & -2.84 & & \\
\hline & & $(0.85)$ & $(0.94)$ & $(1.90)$ & & \\
\hline INT & & & & & -0.01 & -0.32 \\
\hline & & & & & $(0.42)$ & $(0.39)$ \\
\hline $\mathrm{INT} \times \mathrm{BG}$ & & & & & $0.95^{*}$ & -0.31 \\
\hline & & & & & $(1.15)$ & $(0.33)$ \\
\hline $\mathrm{INT} \times \mathrm{FSR}_{\mathrm{t}-1}$ & & & & & -0.09 & $0.06^{\dagger}$ \\
\hline & & & & & $(0.08)$ & $(0.04)$ \\
\hline $\mathrm{INT} \times \mathrm{BG} \times \mathrm{FSR}_{\mathrm{t}-1}$ & & & & & $-0.51^{* *}$ & $0.09^{*}$ \\
\hline & & & & & $(0.19)$ & $(0.04)$ \\
\hline Year dummies & Yes & Yes & Yes & Yes & Yes & Yes \\
\hline Wald $\chi^{2}$ & $413.18^{\text {**** }}$ & $455.28^{* * *}$ & $438.75^{* * *}$ & $177.84^{* * * *}$ & $281.86^{* * * *}$ & $203.45^{\text {*** }}$ \\
\hline$N$ & 949 & 949 & 822 & 121 & 295 & 654 \\
\hline
\end{tabular}

Notes: Standard errors are presented in parentheses. $\uparrow, *, * *$, and $* * *$ denote statistical significance at $10 \%, 5 \%, 1 \%, 0.1 \%$ levels, respectively (two-tailed tests). 
Table 5 Supplementary test of resource allocation mechanisms using a solvency ratio as the dependent variable

\begin{tabular}{|c|c|c|c|c|c|}
\hline & \multicolumn{3}{|c|}{ Full Sample } & \multirow{2}{*}{$\begin{array}{c}\text { China } \\
\text { Model4 }\end{array}$} & \multirow{2}{*}{$\begin{array}{c}\text { India } \\
\text { Model5 } \\
\end{array}$} \\
\hline & Model1 & Model2 & Model3 & & \\
\hline Intercept & $\begin{array}{c}64.57^{* * *} \\
(5.44)\end{array}$ & $\begin{array}{c}65.48^{* * *} \\
(5.46)\end{array}$ & $\begin{array}{c}63.08^{* * *} \\
(5.55)\end{array}$ & $\begin{array}{c}63.66^{* * * *} \\
(7.37)\end{array}$ & $\begin{array}{c}64.82^{* * * *} \\
(8.34)\end{array}$ \\
\hline Firm size & $\begin{array}{c}-1.92^{* * *} \\
(0.42)\end{array}$ & $\begin{array}{c}-1.88^{* * *} \\
(0.42)\end{array}$ & $\begin{array}{c}-1.96^{* * *} \\
(0.43)\end{array}$ & $\begin{array}{c}-1.77^{* * * *} \\
(0.56)\end{array}$ & $\begin{array}{c}-2.09^{* * * *} \\
(0.66)\end{array}$ \\
\hline Firm age & $\begin{array}{c}0.00 \\
(0.02)\end{array}$ & $\begin{array}{c}0.00 \\
(0.02)\end{array}$ & $\begin{array}{c}0.00 \\
(0.03)\end{array}$ & $\begin{array}{c}0.00 \\
(0.10)\end{array}$ & $\begin{array}{c}0.00 \\
(0.02)\end{array}$ \\
\hline Sales growth & $\begin{array}{c}0.00 \\
(0.00)\end{array}$ & $\begin{array}{c}0.00 \\
(0.00)\end{array}$ & $\begin{array}{c}0.00 \\
(0.00)\end{array}$ & $\begin{array}{c}0.00 \\
(0.00)\end{array}$ & $\begin{array}{c}0.00 \\
(0.00)\end{array}$ \\
\hline Net profit margin & $\begin{array}{c}0.50^{* * * *} \\
(0.04)\end{array}$ & $\begin{array}{c}0.51^{* * * *} \\
(0.04)\end{array}$ & $\begin{array}{c}0.49^{* * * *} \\
(0.04)\end{array}$ & $\begin{array}{c}0.52^{* * * *} \\
(0.05)\end{array}$ & $\begin{array}{c}0.49^{* * *} \\
(0.06)\end{array}$ \\
\hline State & $\begin{array}{l}-0.59 \\
(0.98)\end{array}$ & $\begin{array}{l}-0.46 \\
(0.98)\end{array}$ & $\begin{array}{l}-0.58 \\
(1.04)\end{array}$ & $\begin{array}{c}0.25 \\
(1.20)\end{array}$ & $\begin{array}{l}-0.98 \\
(2.62)\end{array}$ \\
\hline IND ownership & $\begin{array}{c}-0.06^{* * *} \\
(0.02)\end{array}$ & $\begin{array}{c}-0.06^{* * *} \\
(0.02)\end{array}$ & $\begin{array}{l}-0.04 \\
(0.03)\end{array}$ & $\begin{array}{l}0.24^{*} \\
(0.10)\end{array}$ & $\begin{array}{l}-0.06^{*} \\
(0.03)\end{array}$ \\
\hline SFI ownership & $\begin{array}{c}0.02 \\
(0.04)\end{array}$ & $\begin{array}{c}0.02 \\
(0.04)\end{array}$ & $\begin{array}{c}0.03 \\
(0.04)\end{array}$ & $\begin{array}{l}-0.04 \\
(0.07)\end{array}$ & $\begin{array}{c}0.07 \\
(0.05)\end{array}$ \\
\hline FOR ownership & $\begin{array}{c}0.02 \\
(0.03)\end{array}$ & $\begin{array}{c}0.02 \\
(0.03)\end{array}$ & $\begin{array}{c}0.03 \\
(0.03)\end{array}$ & $\begin{array}{c}0.06 \\
(0.07)\end{array}$ & $\begin{array}{c}0.02 \\
(0.03)\end{array}$ \\
\hline Market power & $\begin{array}{l}-2.52^{\dagger} \\
(1.44)\end{array}$ & $\begin{array}{l}-2.61^{\dagger} \\
(1.44)\end{array}$ & $\begin{array}{l}-2.34 \\
(1.46)\end{array}$ & $\begin{array}{l}-2.46 \\
(2.22)\end{array}$ & $\begin{array}{l}-2.68 \\
(1.91)\end{array}$ \\
\hline BG size & $\begin{array}{c}0.04 \\
(0.03)\end{array}$ & $\begin{array}{c}0.04 \\
(0.03)\end{array}$ & $\begin{array}{c}0.04 \\
(0.03)\end{array}$ & $\begin{array}{c}0.03 \\
(0.03)\end{array}$ & $\begin{array}{c}0.14 \\
(0.18)\end{array}$ \\
\hline BG diversification & $\begin{array}{l}-0.21^{*} \\
(0.11)\end{array}$ & $\begin{array}{l}-0.21^{*} \\
(0.11)\end{array}$ & $\begin{array}{l}-0.21^{\dagger} \\
(0.11)\end{array}$ & $\begin{array}{c}0.06 \\
(0.27)\end{array}$ & $\begin{array}{l}-0.35^{*} \\
(0.16)\end{array}$ \\
\hline $\mathrm{FSR}_{\mathrm{t}-1}$ & $\begin{array}{l}0.21^{* * *} \\
(0.07)\end{array}$ & $\begin{array}{l}-0.06 \\
(0.09)\end{array}$ & $\begin{array}{l}0.25^{*} \\
(0.11)\end{array}$ & $\begin{array}{l}-0.11 \\
(0.11)\end{array}$ & $\begin{array}{l}0.45^{* * *} \\
(0.17)\end{array}$ \\
\hline BG & & $\begin{array}{c}0.60 \\
(1.07)\end{array}$ & $\begin{array}{c}3.02^{\dagger} \\
(1.68)\end{array}$ & $\begin{array}{l}-0.66 \\
(1.65)\end{array}$ & $\begin{array}{l}3.48^{*} \\
(1.70)\end{array}$ \\
\hline $\mathrm{BG} \times \mathrm{FSR}_{\mathrm{t}-1}$ & & $\begin{array}{l}2.28^{*} \\
(0.96)\end{array}$ & $\begin{array}{l}-3.44^{*} \\
(1.70)\end{array}$ & $\begin{array}{l}2.75^{*} \\
(1.10)\end{array}$ & $\begin{array}{l}-3.38^{*} \\
(1.41)\end{array}$ \\
\hline China & & & $\begin{array}{c}2.38 \\
(1.94)\end{array}$ & & \\
\hline China $\times$ BG & & & $\begin{array}{l}-3.07 \\
(1.94)\end{array}$ & & \\
\hline China $\times \mathrm{FSR}_{\mathrm{t}-1}$ & & & $\begin{array}{l}-0.46^{*} \\
(0.19)\end{array}$ & & \\
\hline China $\times B G \times F_{S R} R_{t-1}$ & & & $\begin{array}{l}6.79^{* *} \\
(2.17)\end{array}$ & & \\
\hline Year dummies & Yes & Yes & Yes & Yes & Yes \\
\hline Wald $\chi^{2}$ & $262.18^{* * *}$ & $263.01^{* * *}$ & $274.17^{* * *}$ & $154.66^{* * *}$ & $124.51^{\text {**** }}$ \\
\hline$N$ & 1872 & 1872 & 1872 & 1123 & 749 \\
\hline
\end{tabular}


Table 6 Supplementary test of resource allocation mechanisms using firm performance (adjusted $\mathrm{ROA}$ ) as the dependent variable

\begin{tabular}{|c|c|c|c|c|c|c|}
\hline & $\frac{\text { Full sample }}{\text { Model } 1}$ & $\frac{\text { China }}{\text { Model } 2}$ & $\underline{\text { India }}$ Model 3 & $\frac{\text { Full sample }}{\text { Model } 4}$ & $\frac{\text { China }}{\text { Model } 5}$ & $\underline{\text { India }}$ Model 6 \\
\hline Intercept & $\begin{array}{c}5.636^{*} \\
(2.754)\end{array}$ & $\begin{array}{c}5.401^{*} \\
(2.474)\end{array}$ & $\begin{array}{c}13.48 \\
(9.358)\end{array}$ & $\begin{array}{c}7.618^{* * *} \\
(1.875)\end{array}$ & $\begin{array}{c}6.090^{*} \\
(2.527)\end{array}$ & $\begin{array}{l}14.05^{* * *} \\
(2.706)\end{array}$ \\
\hline Firm size & $\begin{array}{l}-0.289 \\
(0.182)\end{array}$ & $\begin{array}{l}-0.163 \\
(0.185)\end{array}$ & $\begin{array}{l}-1.381^{*} \\
(0.702)\end{array}$ & $\begin{array}{c}-0.475^{\text {**** }} \\
(0.144)\end{array}$ & $\begin{array}{l}-0.195 \\
(0.189)\end{array}$ & $\begin{array}{c}-1.017^{* * * *} \\
(0.216)\end{array}$ \\
\hline Firm age & $\begin{array}{l}-0.015 \\
(0.024)\end{array}$ & $\begin{array}{l}-0.025 \\
(0.038)\end{array}$ & $\begin{array}{l}-0.016 \\
(0.026)\end{array}$ & $\begin{array}{l}-0.004 \\
(0.009)\end{array}$ & $\begin{array}{l}-0.034 \\
(0.039)\end{array}$ & $\begin{array}{c}-0.002 \\
(0.008)\end{array}$ \\
\hline IPO age & $\begin{array}{l}-0.036 \\
(0.046)\end{array}$ & $\begin{array}{l}-0.063 \\
(0.059)\end{array}$ & $\begin{array}{c}0.020 \\
(0.071)\end{array}$ & $\begin{array}{c}0.004 \\
(0.025)\end{array}$ & $\begin{array}{l}-0.069 \\
(0.061)\end{array}$ & $\begin{array}{c}0.032 \\
(0.025)\end{array}$ \\
\hline Sales growth & $\begin{array}{c}0.001 \\
(0.001)\end{array}$ & $\begin{array}{c}0.001 \\
(0.001)\end{array}$ & $\begin{array}{c}0.008 \\
(0.007)\end{array}$ & $\begin{array}{c}0.0003^{* * *} \\
(0.0001)\end{array}$ & $\begin{array}{c}0.001 \\
(0.001)\end{array}$ & $\begin{array}{c}0.0003^{* * * *} \\
(0.0001)\end{array}$ \\
\hline Leverage & $\begin{array}{l}-0.009 \\
(0.045)\end{array}$ & $\begin{array}{l}-0.016 \\
(0.045)\end{array}$ & $\begin{array}{c}22.53^{* * * *} \\
(4.362)\end{array}$ & $\begin{array}{c}0.167^{* * *} \\
(0.027)\end{array}$ & $\begin{array}{l}-0.013 \\
(0.045)\end{array}$ & $\begin{array}{c}0.302^{* * * *} \\
(0.032)\end{array}$ \\
\hline State & $\begin{array}{l}-0.298 \\
(0.414)\end{array}$ & $\begin{array}{l}-0.359 \\
(0.419)\end{array}$ & $\begin{array}{c}2.127 \\
(2.317)\end{array}$ & $\begin{array}{l}-0.439 \\
(0.355)\end{array}$ & $\begin{array}{l}-0.130 \\
(0.437)\end{array}$ & $\begin{array}{c}0.233 \\
(0.971)\end{array}$ \\
\hline State $\times F_{S R} R_{t-1}$ & $\begin{array}{l}-0.046 \\
(0.373)\end{array}$ & $\begin{array}{c}0.050 \\
(0.381)\end{array}$ & $\begin{array}{l}-3.515 \\
(7.701)\end{array}$ & $\begin{array}{c}0.636^{*} \\
(0.280)\end{array}$ & $\begin{array}{l}-0.119 \\
(0.402)\end{array}$ & $\begin{array}{c}2.829^{*} \\
(1.295)\end{array}$ \\
\hline IND ownership & $\begin{array}{c}0.011 \\
(0.023)\end{array}$ & $\begin{array}{c}0.042 \\
(0.033)\end{array}$ & $\begin{array}{c}0.011 \\
(0.029)\end{array}$ & $\begin{array}{c}0.004 \\
(0.009)\end{array}$ & $\begin{array}{c}0.044 \\
(0.034)\end{array}$ & $\begin{array}{c}0.004 \\
(0.009)\end{array}$ \\
\hline SFI ownership & $\begin{array}{c}0.035 \\
(0.020)\end{array}$ & $\begin{array}{c}0.020 \\
(0.022)\end{array}$ & $\begin{array}{c}0.120^{*} \\
(0.054)\end{array}$ & $\begin{array}{c}0.014 \\
(0.013)\end{array}$ & $\begin{array}{c}0.021 \\
(0.022)\end{array}$ & $\begin{array}{c}0.011 \\
(0.016)\end{array}$ \\
\hline FOR ownership & $\begin{array}{c}0.022 \\
(0.021)\end{array}$ & $\begin{array}{c}0.019 \\
(0.024)\end{array}$ & $\begin{array}{c}0.003 \\
(0.036)\end{array}$ & $\begin{array}{c}0.014 \\
(0.010)\end{array}$ & $\begin{array}{c}0.027 \\
(0.024)\end{array}$ & $\begin{array}{c}0.017 \\
(0.011)\end{array}$ \\
\hline Market power & $\begin{array}{l}-0.383 \\
(0.687)\end{array}$ & $\begin{array}{l}-0.613 \\
(0.715)\end{array}$ & $\begin{array}{l}-0.874 \\
(2.110)\end{array}$ & $\begin{array}{l}-0.136 \\
(0.479)\end{array}$ & $\begin{array}{l}-0.685 \\
(0.730)\end{array}$ & $\begin{array}{c}0.775 \\
(0.602)\end{array}$ \\
\hline BG size & $\begin{array}{l}-0.065 \\
(0.041)\end{array}$ & $\begin{array}{l}-0.060 \\
(0.042)\end{array}$ & $\begin{array}{l}-0.075 \\
(0.173)\end{array}$ & $\begin{array}{l}-0.065 \\
(0.033)\end{array}$ & $\begin{array}{l}-0.048 \\
(0.045)\end{array}$ & $\begin{array}{l}-0.028 \\
(0.056)\end{array}$ \\
\hline $\mathrm{BG}$ diversification & $\begin{array}{c}0.045 \\
(0.069)\end{array}$ & $\begin{array}{c}0.072 \\
(0.083)\end{array}$ & $\begin{array}{l}-0.013 \\
(0.143)\end{array}$ & $\begin{array}{c}0.062 \\
(0.039)\end{array}$ & $\begin{array}{c}0.060 \\
(0.087)\end{array}$ & $\begin{array}{c}0.037 \\
(0.050)\end{array}$ \\
\hline $\mathrm{FSR}_{\mathrm{t}-1}$ & $\begin{array}{c}0.560^{\text {***** }} \\
(0.044)\end{array}$ & $\begin{array}{c}0.521^{* * * *} \\
(0.046)\end{array}$ & $\begin{array}{l}0.392^{* * *} \\
(0.135)\end{array}$ & $\begin{array}{c}0.439^{* * * *} \\
(0.032)\end{array}$ & $\begin{array}{c}0.496^{* * * *} \\
(0.047)\end{array}$ & $\begin{array}{c}0.345^{* * * *} \\
(0.049)\end{array}$ \\
\hline BG & $\begin{array}{c}0.248 \\
(0.473)\end{array}$ & $\begin{array}{c}0.276 \\
(0.515)\end{array}$ & $\begin{array}{l}-0.190 \\
(1.551)\end{array}$ & $\begin{array}{l}1.512^{*} \\
(0.593)\end{array}$ & $\begin{array}{c}1.714 \\
(0.885)\end{array}$ & $\begin{array}{l}1.603^{*} \\
(0.810)\end{array}$ \\
\hline China & $\begin{array}{c}0.737 \\
(1.309)\end{array}$ & & & $\begin{array}{l}1.318^{*} \\
(0.589)\end{array}$ & & \\
\hline Debt tie & $\begin{array}{c}-0.371^{\text {**** }} \\
(0.107)\end{array}$ & $\begin{array}{c}-0.807^{* * *} \\
(0.136)\end{array}$ & $\begin{array}{c}0.165 \\
(0.283)\end{array}$ & & & \\
\hline Debt tie $\times F_{S S R}$ & $\begin{array}{c}0.634^{* * *} \\
(0.180)\end{array}$ & $\begin{array}{c}1.457^{* * *} \\
(0.240)\end{array}$ & $\begin{array}{l}-0.104 \\
(0.261)\end{array}$ & & & \\
\hline Equity tie & & & & $\begin{array}{c}-0.042^{* *} \\
(0.013)\end{array}$ & $\begin{array}{c}-0.070^{* * * *} \\
(0.021)\end{array}$ & $\begin{array}{l}-0.033^{*} \\
(0.016)\end{array}$ \\
\hline Equity tie $\times F R_{t-1}$ & & & & $\begin{array}{l}0.002^{*} \\
(0.001)\end{array}$ & $\begin{array}{l}0.005^{* * * *} \\
(0.001)\end{array}$ & $\begin{array}{c}0.002 \\
(0.001)\end{array}$ \\
\hline Year dummies & Yes & Yes & Yes & Yes & Yes & Yes \\
\hline Wald $\chi^{2}$ & $521.53 * * *$ & $532.24 * * *$ & $106.99 * * *$ & $785.44 * * *$ & $493.97 * * *$ & $364.44 * * *$ \\
\hline$N$ & 1191 & 1125 & 66 & 1814 & 1125 & 689 \\
\hline
\end{tabular}

Notes: Standard errors in parentheses. $\dagger, *, * *$, and $* * *$ denote statistical significance at $10 \%, 5 \%$, $1 \%$, and $0.1 \%$ levels, respectively (two-tailed tests). 
Table 7 Supplementary test of resource allocation mechanisms using debt tie (direct borrowing from BGs) as the dependent variable (subsample of BG firms only)

\begin{tabular}{|c|c|c|c|c|}
\hline & \multicolumn{2}{|c|}{ Full Sample } & \multirow{2}{*}{$\begin{array}{c}\text { China } \\
\text { Model3 }\end{array}$} & \multirow{2}{*}{$\begin{array}{c}\text { India } \\
\text { Model4 }\end{array}$} \\
\hline & Model1 & Model2 & & \\
\hline \multirow[t]{2}{*}{ Intercept } & $0.506^{* *}$ & 0.296 & $0.513^{*}$ & -0.119 \\
\hline & $(0.193)$ & $(0.236)$ & $(0.201)$ & $(0.153)$ \\
\hline \multirow[t]{2}{*}{ Firm size } & $-0.046^{* * *}$ & $-0.046^{* * *}$ & $-0.054^{* * * *}$ & 0.009 \\
\hline & $(0.013)$ & $(0.013)$ & $(0.013)$ & $(0.010)$ \\
\hline \multirow[t]{2}{*}{ Firm age } & $-0.007^{* * *}$ & $-0.005^{*}$ & 0.002 & 0.000 \\
\hline & $(0.002)$ & $(0.002)$ & $(0.007)$ & $(0.001)$ \\
\hline \multirow[t]{2}{*}{ IPO age } & $0.017^{* * *}$ & $0.016^{* * *}$ & 0.012 & 0.000 \\
\hline & $(0.004)$ & $(0.004)$ & $(0.007)$ & $(0.003)$ \\
\hline \multirow[t]{2}{*}{ Leverage } & $-0.024^{* * *}$ & $-0.024^{* * *}$ & $-0.031^{* * *}$ & -0.001 \\
\hline & $(0.002)$ & $(0.002)$ & $(0.002)$ & $(0.001)$ \\
\hline \multirow[t]{2}{*}{ State } & 0.008 & -0.013 & 0.007 & $-0.105^{*}$ \\
\hline & $(0.043)$ & $(0.043)$ & $(0.042)$ & $(0.042)$ \\
\hline \multirow[t]{2}{*}{ BG ownership } & $0.003^{* *}$ & $0.002^{*}$ & $0.002^{*}$ & -0.002 \\
\hline & $(0.001)$ & $(0.001)$ & $(0.001)$ & $(0.001)$ \\
\hline \multirow[t]{2}{*}{ Individual ownership } & 0.000 & 0.003 & -0.003 & 0.001 \\
\hline & $(0.002)$ & $(0.002)$ & $(0.011)$ & $(0.000)$ \\
\hline \multirow[t]{2}{*}{ SFI ownership } & 0.000 & 0.000 & 0.002 & $0.004^{* *}$ \\
\hline & $(0.001)$ & $(0.001)$ & $(0.001)$ & $(0.001)$ \\
\hline \multirow[t]{2}{*}{ BG size } & $0.011^{* * *}$ & $0.010^{* * * *}$ & $0.009^{* * * *}$ & 0.005 \\
\hline & $(0.002)$ & $(0.002)$ & $(0.002)$ & $(0.003)$ \\
\hline \multirow[t]{2}{*}{ BG diversification } & $-0.011^{*}$ & -0.007 & -0.006 & $-0.010^{*}$ \\
\hline & $(0.004)$ & $(0.005)$ & $(0.005)$ & $(0.004)$ \\
\hline \multirow[t]{2}{*}{$\mathrm{FSR}_{\mathrm{t}-1}$} & $0.006^{* *}$ & -0.006 & $0.007^{* * *}$ & 0.001 \\
\hline & $(0.002)$ & $(0.007)$ & $(0.002)$ & $(0.001)$ \\
\hline \multirow[t]{2}{*}{ China } & & $0.273^{*}$ & & \\
\hline & & $(0.130)$ & & \\
\hline \multirow[t]{2}{*}{ China $\times F_{S R} R_{t-1}$} & & $0.089^{*}$ & & \\
\hline & & $(0.045)$ & & \\
\hline Year dummies & Yes & Yes & Yes & Yes \\
\hline Wald $\chi^{2}$ & 234.91 & $246.48 * * *$ & $300.07 * * *$ & $24.71 * *$ \\
\hline$N$ & 556 & 556 & 516 & 40 \\
\hline
\end{tabular}

Notes: Standard errors are presented in parentheses. $\uparrow, *, * *$, and $* * *$ denote statistical significance at $10 \%, 5 \%, 1 \%$, and $0.1 \%$ levels, respectively (two-tailed tests). 